\title{
NEW SYNTHETIC CAFFEINE ANALOGS AS MODULATORS OF THE CHOLINERGIC SYSTEM
}

\author{
Camila Fabiani ${ }^{1}$, Brunella Biscussi ${ }^{2}$, Juan P. Munafó ${ }^{1}$, Ana P. Murray ${ }^{2 *}$, Jeremías \\ Corradi $^{1 *}$, Silvia S. Antollini ${ }^{1^{*}+}$ \\ ${ }^{1}$ Instituto de Investigaciones Bioquímicas de Bahía Blanca, Departamento de Biología, Bioquímica y \\ Farmacia, Universidad Nacional del Sur y Consejo Nacional de Investigaciones Científicas y Técnicas, \\ Camino La Carrindanga km 7, 8000 Bahía Blanca, Argentina \\ ${ }^{2}$ Instituto de Química del Sur, Departamento de Química, Universidad Nacional del Sur y Consejo \\ Nacional de Investigaciones Científicas y Técnicas, Av. Alem 1253, 8000 Bahía Blanca, Argentina \\ ${ }^{*}$ Corresponding authors: silviant@criba.edu.ar; jcorradi@criba.edu.ar
}


RUNNING TITTLE: Caffeine analogs as modulators of the cholinergic system

Corresponding author: Silvia Susana Antollini, Instituto de Investigaciones Bioquímicas de Bahía Blanca, Departamento de Biología, Bioquímica y Farmacia, Universidad Nacional del Sur y Consejo Nacional de Investigaciones Científicas y Técnicas, Camino La Carrindanga km 7, 8000 Bahía Blanca, Argentina. Telephone: 0054291437 5574. silviant@criba.edu.ar

\section{Document Statistics:}

Number of text pages: 38

Number of tables: 2

Number figures: 8 (+ 16 suppl)

Number of references: 68

Number of words in the Abstract: 242

Number of words in the Introduction: 712

Number of words in the Discussion: 1498

\section{Non-standard Abbreviations}

Carb, carbamylcholine

BBE, best binding energy

CAS, catalytic site

CrV, crystal violet

$D$, desensitized state

DMF, dimethylformamide

DTNB, 5'5'-dithio-bis(2-nitrobenzoic acid).

HEPES, 4-(2-hydroxyethyl)-1-piperazineethanesulfonic acid

$\mathrm{K}_{\mathrm{D}}$, dissociation constant

nAChR, nicotinic acetylcholine receptor

PAMs, positive allosteric modulators

PAS, peripheral anionic site

PNU, PNU-120596, N-(5-Chloro-2,4- dimethoxyphenyl)-N'-(5-methyl-3-isoxazolyl)-urea.

$R$, resting state 
Molecular Pharmacology Fast Forward. Published on December 30, 2021 as DOI: 10.1124/molpharm.121.000415

This article has not been copyedited and formatted. The final version may differ from this version.

\section{ABSTRACT}

Alzheimer's disease $(A D)$ is a multifactorial neurodegenerative disorder. Since cholinergic deficit is a major factor in this disease, two molecular targets for its treatment are the acetylcholinesterase (AChE) and the nicotinic acetylcholine receptors (nAChRs). Given that caffeine is a natural compound that behaves as an AChE inhibitor and as a partial agonist of nAChRs, the aim of this work was to synthetize more potent bifunctional caffeine analogs that modulate these two molecular targets. To this end, a theophylline structure was connected to a pyrrolidine structure through a methylene chain of different lengths ( 3 to 7 carbon atoms) to give compounds 7-11. All caffeine derivatives inhibited the AChE, of which compound 11 showed the strongest effect. Electrophysiological studies showed that all compounds behave as agonists of the muscle and the neuronal $\alpha 7 \mathrm{nAChR}$ with greater potency than caffeine. To explore if the different analogs could affect the $\mathrm{nAChR}$ conformational state, the $\mathrm{nAChR}$ conformationalsensitive probe crystal violet ( $\mathrm{CrV}$ ) was used. Compounds 9 and 10 conduced the nAChR to a different conformational state comparable with a control nAChR desensitized state. Finally, molecular docking experiments showed that all derivatives interacted with both the catalytic and anionic sites of AChE and with the orthosteric binding site of the nAChR. Thus, the new synthetized compounds can inhibit the AChE and activate muscle and $\alpha 7 \mathrm{nAChRs}$ with greater potency than caffeine, which suggests that they could be useful leaders for the development of new therapies for the treatment of different neurological diseases. 
Molecular Pharmacology Fast Forward. Published on December 30, 2021 as DOI: 10.1124/molpharm.121.000415

This article has not been copyedited and formatted. The final version may differ from this version.

\section{SIGNIFICANCE STATEMENT}

In this work we synthetized caffeine derivatives which can inhibit the AChE and activate both muscle and $\alpha 7 \mathrm{nAChRs}$ with higher potency than caffeine. These analogs can be divided into two groups: a non-desensitizing and a desensitizing nAChR group. From the nAChR-non desensitizing group, we propose compound 11 as the most interesting analog for further studies since it inhibits AChE with the highest potency and activates the $\mathrm{nAChRs}$ in the picomolar range without inducing receptor desensitization. 
Molecular Pharmacology Fast Forward. Published on December 30, 2021 as DOI: 10.1124/molpharm.121.000415

This article has not been copyedited and formatted. The final version may differ from this version.

\section{INTRODUCTION}

Alzheimer's Disease (AD), the most prevalent neurodegenerative disorder in the elderly, is mainly characterized by progressive cognitive decline. The rationale for the cholinergic hypothesis of AD (Davies and Maloney, 1976; Perry et al., 1981; Contestabile, 2011; Hampel et al., 2018) is that there is a decrease in the total amount of acetylcholine receptors (AChRs) because of the progressive death of cholinergic neurons (Whitehouse et al., 1986; Paterson and Nordberg, 2000; Ma and Qian, 2019). Since the loss of cognitive functions is strongly correlated with a disruption in the cholinergic neurotransmission, an enhancement of this neurotransmission either by inhibition of the acetylcholinesterase (AChE) or potentiation of the nicotinic acetylcholine receptors (nAChRs) could improve memory and cognition (Craig et al., 2011).

The AChE is the enzyme that terminates the acetylcholine (ACh) signal at the postsynaptic membrane. The inhibition of this enzyme therefore increases the amount of ACh that can bind to the nAChRs. The AChE active cavity involves two sites: the catalytic site (CAS), which consists of two "subsites" (the anionic subsite which arranges the substrate in a suitable orientation, and the ester subsite which is responsible for the catalytic action of the enzyme) and the peripheral anionic site (PAS), a region that is an important target for interaction with different molecules, among which are the amyloid peptides (Inestrosa et al., 2005). Current pharmacological agents, such as tacrine, donepezil, rivastigmine, and galantamine, are used to inhibit AChE (Martorana et al., 2010). Unfortunately, these drugs can alleviate the symptoms of AD but are unable to prevent disease progression (Selkoe, 2012; Singh et al., 2013).

Other interesting molecular target for the treatment of $A D$ are the nAChRs. They are integral membrane pentameric proteins that belong to the Cys-loop family of ligand-gated ion channels (Karlin and Akabas, 1995; Le Novère and Changeux, 1995). These receptors contain an extracellular domain, which carries the binding site; a transmembrane region, formed by four transmembrane segments from each subunit (M1-M4), and an intracellular region that contains sites for receptor modulation and determinants of channel conductance (Corradi and Bouzat, 2016; Morales-Perez et al., 2016). The binding of its natural agonist, ACh, triggers a conformational change that ends in the opening of the ion channel and the flux of positive ions across the membrane, causing membrane depolarization (McKay et al., 2007; Pohanka, 2012; 
Molecular Pharmacology Fast Forward. Published on December 30, 2021 as DOI: 10.1124/molpharm.121.000415

This article has not been copyedited and formatted. The final version may differ from this version.

Corradi and Bouzat, 2016).

In vertebrates, seventeen $\mathrm{nAChR}$ subunits combine to yield a great variety of receptors. Muscle nAChRs, which have been the model for biophysical and pharmacological studies of all the nicotinic receptors family, are heteropentameric receptors formed by the combination of two $\alpha 1$ subunits and one of each $\beta, \varepsilon$ and $\delta$ subunit. The homomeric $\alpha 7$ and the $\alpha 4 \beta 2$ neuronal receptors are the most abundant nAChRs in the mammalian brain. These receptors are widely dispersed throughout the central nervous system, and their unique distribution within the structures involved in cognition implicates them as important potential targets for neurodegenerative diseases. The most vulnerable neurons in $A D$ are those expressing high levels of $\alpha 7$ neuronal nAChRs (Dani and Bertrand, 2007) being that the reason why $\alpha 7$ receptor is the most implicated and studied in the mentioned disease, as well as in other neurological disorders such as Parkinson's disease and schizophrenia (D'Andrea and Nagele, 2006; Dani and Bertrand, 2007), and has emerged as a potential therapeutic target (Pohanka, 2012).

Although a great effort has been made to develop specific drugs to potentiate nAChRs, nowadays AChE inhibition is the only approved treatment to slow the symptoms of mild to moderate $A D$. Commercial $A C h E$ inhibitors are considered indirect $\mathrm{nAChR}$ agonists that locally increase endogenous neurotransmitter levels. Thus, much effort is put on the design of multitarget drugs that can both inhibit $\mathrm{AChE}$ and directly improve nAChR function. In a previous work (Fabiani et al., 2018) we confirmed that caffeine inhibits AChE activity and demonstrated that it is an agonist of nAChRs, thus becoming an interesting lead compound for the design of new molecules.

The aim of this work was to obtain more potent caffeine analogs. We synthetized five compounds using as initial substrates theophylline, which bears similarity to caffeine, and pyrrolidine, whose structure is present in nicotine's molecule. We here demonstrate that the synthetized compounds behave as bifunctional drugs that can inhibit the AChE and activate nAChRs with higher potency than caffeine. 
Molecular Pharmacology Fast Forward. Published on December 30, 2021 as DOI: 10.1124/molpharm.121.000415

This article has not been copyedited and formatted. The final version may differ from this version.

\section{MATERIALS AND METHODS}

\section{Materials}

Torpedo californica specimens obtained from the Pacific coast of California (Aquatic Research Consulants, San Pedro, CA, USA) were killed by pithing, and the electric organs were dissected and stored at $-70{ }^{\circ} \mathrm{C}$ until use.

All the chemicals employed were of the best available grade (Aldrich, Merck) and were used without further purification. AChE from electric eel (type VI-S), 5,5'-dithiobis(2- nitrobenzoic acid) (DTNB), acetylthiocholine iodide (ATChl), tacrine, crystal violet (CrV) and all other drugs were obtained from Sigma Aldrich. PNU-120596 [N-(5-Chloro-2,4-dimethoxyphenyl)-N0-(5methyl-3-isoxazolyl)-urea] (PNU) was obtained from Tocris Biosciences (Bristol, UK).

\section{Methods}

\section{Synthesis of caffeine analogs}

General chemistry

${ }^{1} \mathrm{H}$ and ${ }^{13} \mathrm{C}$ NMR spectra including COSY, HSQC, HMBC experiments were recorded on a Bruker Avance ARX-300 spectrophotometer at room temperature in $\mathrm{CDCl}_{3}$. Chemical shifts $(\delta)$ are reported in parts per million $(\mathrm{ppm})$ from tetramethylsilane (TMS, $\delta=0.00 \mathrm{ppm}$ ). All melting points $(\mathrm{mp})$ were determined using a Reichert melting points apparatus.

Column chromatography was carried out with Merck silica gel 60 (0.2-0.63 mm, 240400 mesh). The progress of the reactions was controlled using silica gel-60 F 254 chromatofoils (Merck). The development of thin layer chromatograms was performed by visualization with ultraviolet light of wavelengths 254 and $366 \mathrm{~nm}$ and/or in p-anisaldehyde developing stain.

Microwave assisted reactions were performed in a microwave reactor CEM Discover Benchmate oven, CEM Corp, Matthews, North Carolina, USA.

All derivatives were rigorously characterized by NMR spectroscopy. For new compounds, copies of ${ }^{1} \mathrm{H},{ }^{13} \mathrm{C}$, DEPT and HSQC NMR graphical spectra are also provided (Supplementary Figures S3-S16).

\section{General procedure for the synthesis of compounds 2-6}

To a solution of compound $1(0,1802 \mathrm{~g}, 1.0 \mathrm{mmol})$ and anhydrous $\mathrm{K}_{2} \mathrm{CO}_{3}(207 \mathrm{mg}, 1.5$ mmol) in dry dimethylformamide $(1 \mathrm{~mL})$, the corresponding $\alpha, \omega$-dibromoalkane was added (2 
$\mathrm{mmol})$. The solution was placed in a $10-\mathrm{mL}$ closed system microwave vessel with a magnetic stirrer and was irradiated for $10 \mathrm{~min}$ at $80^{\circ} \mathrm{C}$ with the following fixed conditions: standard mode, $150 \mathrm{~W}, 5$-minute heating ramp to reach working temperature, medium stirring, max. power off. The solvent was subsequently removed by addition of distilled $\mathrm{H}_{2} \mathrm{O}(3 \mathrm{~mL})$ and extraction with AcOEt $(3 \times 2 \mathrm{~mL})$. The organic phase was dried over anh. $\mathrm{Na}_{2} \mathrm{SO}_{4}$, filtered and the solvent was evaporated to afford the desired product. The residue was purified by column chromatography on silica gel 60 (70-230 mesh) with dichlomethane/methanol (90:10) to afford the desired ether (yields of 31 to $42 \%$ ).

\section{7-(3-bromopropyl)-1,3-dimethyl-3,7-dihydro-1H-purine-2,6-dione (2)}

Compound 1 was treated with 1,3-dibromopropane $(204 \mu \mathrm{L})$ according to the general procedure to yield compound 2 as a white solid (43\% yield); mp: $133-135^{\circ} \mathrm{C}$. ${ }^{1} \mathrm{H}$ NMR $(300 \mathrm{MHz}$, $\left.\mathrm{CDCl}_{3}, \mathrm{ppm}\right) \delta 7.64(s, 1 \mathrm{H}), 4.47(t, J=6.5 \mathrm{~Hz}, 2 \mathrm{H}), 3.60(s, 3 \mathrm{H}), 3.41(s, 3 \mathrm{H}), 3.33(t, J=6.0 \mathrm{~Hz}$, $2 \mathrm{H}), 2.46(p, J=6.3 \mathrm{~Hz}, 2 \mathrm{H}) ;{ }^{13} \mathrm{C} \operatorname{NMR}\left(75 \mathrm{MHz}, \mathrm{CDCl}_{3}, \mathrm{ppm}\right) \delta 155.2,151.8,149.4,141.6$, $106.8,45.4,32.7,29.9,29.6,28.1$.

\section{7-(4-bromobutyl)-1,3-dimethyl-3,7-dihydro-1H-purine-2,6-dione (3)}

Compound 1 was treated with 1,4-dibromobutane $(280 \mu \mathrm{L})$ according to the general procedure to yield compound 3 as a white solid (32\% yield). ${ }^{1} \mathrm{H}$ NMR $\left(300 \mathrm{MHz}, \mathrm{CDCl}_{3}, \mathrm{ppm}\right) \delta$ $7.65(\mathrm{~s}, 1 \mathrm{H}), 4.36(t, J=7.1 \mathrm{~Hz}, 2 \mathrm{H}), 3.59(\mathrm{~s}, 3 \mathrm{H}), 3.44(\mathrm{~m}, 2 \mathrm{H}), 3.41(\mathrm{~s}, 3 \mathrm{H}), 2.08(p, J=6.9 \mathrm{~Hz}$, 2H), $1.90(p, J=6.4 \mathrm{~Hz}, 2 \mathrm{H}) ;{ }^{13} \mathrm{C}$ NMR $\left(75 \mathrm{MHz}, \mathrm{CDCl}_{3}, \mathrm{ppm}\right) \delta 155.0,151.5,148.8,140.7$, $106.8,46.3,32.4,29.8,29.6,29.3,28.8$.

\section{7-(5-bromopentyl)-1,3-dimethyl-3,7-dihydro-1H-purine-2,6-dione (4)}

Compound 1 was treated with 1,5-dibromopentane $(275 \mu \mathrm{L})$ according to the general procedure to yield compound 4 as a white solid (34\% yield); mp: $83-85^{\circ} \mathrm{C} .{ }^{1} \mathrm{H}$ NMR $(300 \mathrm{MHz}$, $\left.\mathrm{CDCl}_{3}, \mathrm{ppm}\right) \delta 7.56(\mathrm{~s}, 1 \mathrm{H}), 4.30(t, \mathrm{~J}=7.2 \mathrm{~Hz}, 2 \mathrm{H}), 3.59(\mathrm{~s}, 3 \mathrm{H}), 3.41(\mathrm{~s}, 3 \mathrm{H}), 3.42(\mathrm{~m}, 2 \mathrm{H}), 2.02$ - $1.83(m, 4 \mathrm{H}), 1.49(p, \mathrm{~J}=6.4 \mathrm{~Hz}, 2 \mathrm{H}) ;{ }^{13} \mathrm{C}$ NMR $\left(75 \mathrm{MHz}, \mathrm{CDCl}_{3}, \mathrm{ppm}\right) \delta 155.2,151.8,149.1$, $140.9,106.8,47.1,33.3,32.0,30.1,29.9,28.1,25.0$.

\section{7-(6-bromohexyl)-1,3-dimethyl-3,7-dihydro-1H-purine-2,6-dione (5)}


Molecular Pharmacology Fast Forward. Published on December 30, 2021 as DOI: 10.1124/molpharm.121.000415

This article has not been copyedited and formatted. The final version may differ from this version.

Compound 1 was treated with 1,6-dibromohexane (310 $\mu \mathrm{L})$ according to the general procedure to yield compound $\mathbf{5}$ as a white solid (32\% yield). ${ }^{1} \mathrm{H}$ NMR $\left(300 \mathrm{MHz}, \mathrm{CDCl}_{3}, \mathrm{ppm}\right) \delta$ $7.54(s, 1 \mathrm{H}), 4.29(t, \mathrm{~J}=7.2 \mathrm{~Hz}, 2 \mathrm{H}), 3.59(\mathrm{~s}, 3 \mathrm{H}), 3.41(\mathrm{~s}, 3 \mathrm{H}), 3.38(m, 2 \mathrm{H}), 196-1.80(m, 4 \mathrm{H})$, $1.58-1.42(m, 2 \mathrm{H}), 1.43-1.27(m, 2 \mathrm{H}) ;{ }^{13} \mathrm{C} \mathrm{NMR}\left(75 \mathrm{MHz}, \mathrm{CDCl}_{3}, \mathrm{ppm}\right) \delta 155.2,151.8$, $149.1,140.9,107.1,47.2,33.6,32.5,30.8,29.9,28.1,27.6,25.6$.

\section{7-(7-bromoheptyl)-1,3-dimethyl-3,7-dihydro-1H-purine-2,6-dione (6)}

Compound 1 was treated with 1,7-dibromoheptane $(342 \mu \mathrm{L})$ according to the general procedure to yield compound 6 as a white solid $\left(40 \%\right.$ yield); mp: $84-86^{\circ} \mathrm{C} .{ }^{1} \mathrm{H}$ NMR $(300 \mathrm{MHz}$, $\left.\mathrm{CDCl}_{3}, \mathrm{ppm}\right) \delta 7.55(\mathrm{~s}, 1 \mathrm{H}), 4.29(t, \mathrm{~J}=7.2 \mathrm{~Hz}, 2 \mathrm{H}), 3.59(s, 3 \mathrm{H}), 3.41(s, 3 \mathrm{H}), 3.38(m, 2 \mathrm{H}), 196$ - $1.78(m, 4 \mathrm{H}), 1.49-1.30(m, 6 \mathrm{H}) ;{ }^{13} \mathrm{C}$ NMR $\left(75 \mathrm{MHz}, \mathrm{CDCl}_{3}, \mathrm{ppm}\right) \delta 155.2,151.8,149.0$, $140.9,107.1,47.3,33.8,32.5,30.9,29.9,28.2,28.1,28.0,26.3$.

\section{General procedure for the synthesis of compounds $7-11$}

To a solution of 2-6 $(0.1 \mathrm{mmol})$ in dry DMF $(1 \mathrm{~mL})$, pyrrolidine $(0.3 \mathrm{mmol})$ was added. The reaction mixture was placed in a microwave-special closed vial and irradiated for 5-12 min at $100^{\circ} \mathrm{C}(150 \mathrm{~W})$ until the disappearance of the starting compound was detected by TLC. The solvent was subsequently removed by adding distilled $\mathrm{H}_{2} \mathrm{O}(2 \mathrm{~mL})$ and extracting with AcOEt (3 $x 2 \mathrm{~mL}$ ). The organic phase was dried over anh. $\mathrm{Na}_{2} \mathrm{SO}_{4}$, filtered and evaporated under vacuum to afford the desired product (yields 50 to $70 \%$ ).

\section{1,3-dimethyl-7-(3-(pyrrolidin-1-yl)propyl)-3,7-dihydro-1H-purine-2,6-dione (7)}

Intermediate $2(0.239 \mathrm{mmol}, 0.0723 \mathrm{~g})$ was treated with pyrrolidine $(0.76 \mathrm{mmol}, 62.8 \mu \mathrm{l})$ following the general procedure. The reaction mixture was irradiated for $5 \mathrm{~min}$ at $100^{\circ} \mathrm{C}(150$ W). The desired product 7 was obtained as a pale yellow solid (70\%); mp: $55-56{ }^{\circ} \mathrm{C}$. ${ }^{1} \mathrm{H}$ NMR (300 MHz, $\left.\mathrm{CDCl}_{3}, \mathrm{ppm}\right) \delta 7.60(\mathrm{~s}, 1 \mathrm{H}), 4.39(t, \mathrm{~J}=6.5 \mathrm{~Hz}, 2 \mathrm{H}), 3.59(\mathrm{~s}, 3 \mathrm{H}), 3.41(\mathrm{~s}, 3 \mathrm{H}), 2.52-$ $2.44(m, 4 \mathrm{H}), 2.40(t, \mathrm{~J}=6.8 \mathrm{~Hz}, 2 \mathrm{H}), 2.05(p, \mathrm{~J}=6.7 \mathrm{~Hz}, 2 \mathrm{H}), 1.78(p, \mathrm{~J}=3.1 \mathrm{~Hz}, 4 \mathrm{H}) .{ }^{13} \mathrm{C} \mathrm{NMR}$ (75 MHz, $\left.\mathrm{CDCl}_{3}, \mathrm{ppm}\right) \delta 155.1,151.7,148.9,141.6,106.9,53.9,52.1,45.1,29.7,29.4,28.0$, 23.5.

\section{1,3-dimethyl-7-(4-(pyrrolidin-1-yl)butyl)-3,7-dihydro-1H-purine-2,6-dione (8)}


Molecular Pharmacology Fast Forward. Published on December 30, 2021 as DOI: 10.1124/molpharm.121.000415 This article has not been copyedited and formatted. The final version may differ from this version.

Intermediate $3(0.25 \mathrm{mmol}, 0.0803 \mathrm{~g})$ was treated with pyrrolidine $(0.76 \mathrm{mmol}, 62.8 \mu \mathrm{l})$ following the general procedure. The reaction mixture was irradiated for $10 \mathrm{~min}$ at $100^{\circ} \mathrm{C}(150$ W). The desired product 8 was obtained as a brown oil $(65 \%) .{ }^{1} \mathrm{H} \mathrm{NMR}\left(300 \mathrm{MHz}, \mathrm{CDCl}_{3}, \mathrm{ppm}\right)$ $\delta 7.56(s, 1 \mathrm{H}), 4.32(t, \mathrm{~J}=6.5 \mathrm{~Hz}, 2 \mathrm{H}), 3.59(s, 3 \mathrm{H}), 3.41(s, 3 \mathrm{H}), 2.47(p, \mathrm{~J}=7.5 \mathrm{~Hz}, 6 \mathrm{H}), 1.93$ $(p, \mathrm{~J}=7.4 \mathrm{~Hz}, 2 \mathrm{H}), 1.77(p, \mathrm{~J}=3.1 \mathrm{~Hz}, 4 \mathrm{H}) 1.54(p, \mathrm{~J}=7.6 \mathrm{~Hz}, 2 \mathrm{H}) .{ }^{13} \mathrm{C}$ NMR $\left(75 \mathrm{MHz}, \mathrm{CDCl}_{3}\right.$, ppm) $\delta 155.2,151.8,149.0,140.9,107.1,55.8,54.3,47.2,29.8,29.2,28.1,25.9,23.5$.

\section{1,3-dimethyl-7-(5-(pyrrolidin-1-yl)pentyl)-3,7-dihydro-1H-purine-2,6-dione (9)}

Intermediate $4(0.096 \mathrm{mmol}, 0.0317 \mathrm{~g})$ was treated with pyrrolidine $(0.29 \mathrm{mmol}, 24.6 \mu \mathrm{l})$ following the general procedure. The reaction mixture was irradiated for $10 \mathrm{~min}$ at $100^{\circ} \mathrm{C}(150$ W). The desired product 9 was obtained as a brown oil $(47 \%) .{ }^{1} \mathrm{H} \mathrm{NMR}\left(300 \mathrm{MHz}, \mathrm{CDCl}_{3}, \mathrm{ppm}\right)$ $\delta 7.55(s, 1 \mathrm{H}), 4.29(t, \mathrm{~J}=7.1 \mathrm{~Hz}, 2 \mathrm{H}), 3.59(\mathrm{~s}, 3 \mathrm{H}), 3.41(\mathrm{~s}, 3 \mathrm{H}), 2.55-2.48(\mathrm{~m}, 4 \mathrm{H}), 2.48-2.41$ $(m, 2 \mathrm{H}), 1.91(p, \mathrm{~J}=7.4 \mathrm{~Hz}, 2 \mathrm{H}), 1.79(p, \mathrm{~J}=3.1 \mathrm{~Hz}, 4 \mathrm{H}) 1.58(p, \mathrm{~J}=7.5 \mathrm{~Hz}, 2 \mathrm{H}), 1.36(q, \mathrm{~J}=7.6$ $\mathrm{Hz}, 2 \mathrm{H}) .{ }^{13} \mathrm{C} \mathrm{NMR}\left(75 \mathrm{MHz}, \mathrm{CDCl}_{3}, \mathrm{ppm}\right) \delta 155.2,151.8,149.0,140.9,107.1,56.3,54.3,47.3$, $30.9,29.8,28.4,28.1,24.5,23.5(\mathrm{t})$.

\section{1,3-dimethyl-7-(6-(pyrrolidin-1-yl)hexyl)-3,7-dihydro-1H-purine-2,6-dione (10)}

Intermediate $5(0.067 \mathrm{mmol}, 0.023 \mathrm{~g})$ was treated with pyrrolidine $(0.2 \mathrm{mmol}, 16.3 \mu \mathrm{l})$ following the general procedure. The reaction mixture was irradiated for $10 \mathrm{~min}$ at $100^{\circ} \mathrm{C}(150$ W). The desired product 10 was obtained as a brown oil $(72 \%) .{ }^{1} \mathrm{H} \mathrm{NMR}\left(300 \mathrm{MHz}, \mathrm{CDCl}_{3}\right.$, ppm) $\delta 7.54(s, 1 \mathrm{H}), 4.28(t, \mathrm{~J}=7.0 \mathrm{~Hz}, 2 \mathrm{H}), 3.59(\mathrm{~s}, 3 \mathrm{H}), 3.41(\mathrm{~s}, 3 \mathrm{H}), 2.59-2.49(m, 4 \mathrm{H}), 2.45$ $(t, \mathrm{~J}=7.5 \mathrm{~Hz}, 2 \mathrm{H}), 1.88(p, \mathrm{~J}=6.3 \mathrm{~Hz}, 2 \mathrm{H}), 1.80(p . \mathrm{J}=3.1 \mathrm{~Hz}, 4 \mathrm{H}), 1.53(p, \mathrm{~J}=7.4 \mathrm{~Hz}, 2 \mathrm{H}), 1.44$ - $1.29(m, 4 \mathrm{H}) .{ }^{13} \mathrm{C}$ NMR $\left(75 \mathrm{MHz}, \mathrm{CDCl}_{3}, \mathrm{ppm}\right) \delta 155.2,151.8,149.1,140.9,107.1,56.4,54.3$, $47.3,30.9,29.9,28.7,28.1,27.1,26.4,23.5$.

\section{1,3-dimethyl-7-(7-(pyrrolidin-1-yl)heptyl)-3,7-dihydro-1H-purine-2,6-dione (11)}

Intermediate $6(0.10 \mathrm{mmol}, 0.036 \mathrm{~g})$ was treated with pyrrolidine $(0.3 \mathrm{mmol}, 24.6 \mu \mathrm{l})$ following the general procedure. The reaction mixture was irradiated for $12 \mathrm{~min}$ at $80^{\circ} \mathrm{C}(150$ W). The desired product 11 was obtained as a brown oil (45\%). ${ }^{1} \mathrm{H} \mathrm{NMR}\left(300 \mathrm{MHz}, \mathrm{CDCl}_{3}\right.$, ppm) $\delta 7.53(s, 1 \mathrm{H}), 4.28(t, \mathrm{~J}=7.1 \mathrm{~Hz}, 2 \mathrm{H}), 3.59(s, 3 \mathrm{H}), 3.41(s, 3 \mathrm{H}), 2.58-2.48(m, 4 \mathrm{H})$, $2.44(t, \mathrm{~J}=7.5 \mathrm{~Hz}, 2 \mathrm{H}), 1.87$ (os, 2H), 1.79 (os, 4H), 1.53 ( $p, \mathrm{~J}=6.6 \mathrm{~Hz}, 2 \mathrm{H}), 1.39-1.27(m, 6 \mathrm{H})$. 
Molecular Pharmacology Fast Forward. Published on December 30, 2021 as DOI: 10.1124/molpharm.121.000415

This article has not been copyedited and formatted. The final version may differ from this version.

${ }^{13} \mathrm{C}$ NMR $\left(75 \mathrm{MHz}, \mathrm{CDCl}_{3}, \mathrm{ppm}\right) \delta 155.2,151.8,149.0,140.9,107.1,56.5,54.3,47.4,30.9$, $29.9,29.0,28.8,28.1,27.6,26.4,23.5$.

\section{In vitro AChE activity}

Electric eel AChE was used as source of cholinesterase. Inhibitory activity on AChE was determined in vitro by the spectrophotometric method developed by Ellman with slight modifications (Ellman et al., 1961). Buffer phosphate A (8 $\mathrm{mM} \mathrm{K}_{2} \mathrm{HPO}_{4}, 2.3 \mathrm{mM} \mathrm{NaH} \mathrm{PO}_{4}$ ) and B (8 $\mathrm{mM} \mathrm{K}_{2} \mathrm{HPO}_{4}, 2.3 \mathrm{mM} \mathrm{NaH}{ }_{2} \mathrm{PO}_{4}, 0.15 \mathrm{M} \mathrm{NaCl}, 0.05 \%$ Tween 20, $\mathrm{pH}$ 7.6) were used for the dilutions. The lyophilized enzyme, $500 \cup \mathrm{AChE}$, was dissolved in buffer phosphate A to obtain 5 $\mathrm{U} / \mathrm{mL}$ stock solution. For each bioassay, the enzyme was diluted with buffer phosphate $\mathrm{B}$ to produce $0.126 \mathrm{U} / \mathrm{mL}$ enzyme solution. Samples $(500-0.01 \mu \mathrm{M})$ were dissolved in buffer phosphate $\mathrm{B}$ adding $\mathrm{MeOH}(2.5 \%)$ as cosolvent. Finally, the enzyme solution (300 $\mu \mathrm{l})$ and sample solution $(300 \mu \mathrm{l})$ were mixed in a test tube and incubated at room temperature for 60 min. The reaction was initiated by adding $600 \mu \mathrm{l}$ of the substrate solution (0.5 mM DTNB, 0.6 $\mathrm{mM}$ ATChl, $0.1 \mathrm{M} \mathrm{Na}_{2} \mathrm{HPO}_{4}, \mathrm{pH}$ 7.5). Absorbance was read at $405 \mathrm{~nm}$ for $120 \mathrm{~s}$ at $25^{\circ} \mathrm{C}$ (JASCO V-630BIO Spectrophotometer equipped with an EHCS-760 Peltier; Tokyo, Japan). Enzyme activity was measured by comparing reaction rates for the samples to the blank. Tacrine (99\%) was used as the reference inhibitor. All the experiments were performed in triplicate. $I \mathrm{IC}_{50}$ values were determined with the aid of a GraphPad Prism 5 software.

\section{nAChR-rich membranes preparation}

nAChR-rich membrane fragments were prepared from Torpedo californica electric tissue as described previously (Barrantes, 1982). Briefly, electric tissue was chopped into small pieces, homogenized using a Virtis homogenizer under controlled conditions, and submitted to a series of centrifugation steps to obtain $T$. californica crude membranes, ending in a highspeed sucrose gradient centrifugation. The middle fraction obtained corresponds to nAChR-rich membranes with a specific activity of the order of $1.0-1.5 \mathrm{nmol}$ of $\alpha-\mathrm{BTX}$ sites/mg of protein (Barrantes, 1982).

\section{Cell culture}


Molecular Pharmacology Fast Forward. Published on December 30, 2021 as DOI: 10.1124/molpharm.121.000415

This article has not been copyedited and formatted. The final version may differ from this version.

HEK293 cells were transfected with mouse $\alpha, \beta, \delta$ and $\varepsilon$ subunits, for muscle, or human $\alpha 7$ and Ric-3 subunits, for neuronal nAChR expression, as was previously described (Bouzat et al., 1994; daCosta, et al., 2011). Each receptor cDNA subunit was sub-cloned into pRBG4 plasmid for heterologous expression. For electrophysiological measurements, a plasmid encoding green fluorescent protein (GFP) was included in all transfections to allow the identification of transfected cells under fluorescence optics.

\section{nAChR conformational state characterization}

nAChR-rich membranes were resuspended in buffer $\mathrm{A}(150 \mathrm{mM} \mathrm{NaCl}, 0.25 \mathrm{mM} \mathrm{MgCl}$, and $20 \mathrm{mM}$ HEPES buffer, $\mathrm{pH}$ 7.4) at a final concentration of $100 \mu \mathrm{g}$ of protein/ml. nAChR conformational changes were analyzed using crystal violet ( $\mathrm{CrV})$ as described previously (Fabiani et al., 2018). nAChR-rich membranes resuspended in buffer A were incubated for 15 min with pyrrolidine, theophylline or the caffeine analogs 7-11. For the measurements conducted with $\mathrm{nAChR}$ in the desensitized state, T. californica membranes were afterwards incubated with $1 \mathrm{mM}$ of carbamylcholine (carb) for $15 \mathrm{~min}$. The membranes were subsequently titrated with increasing concentrations of $\mathrm{CrV}$ (in buffer A). After each addition of CrV, the samples were incubated for $15 \mathrm{~min}$ before obtaining the fluorescence emission spectra. $\mathrm{CrV}$ was excited at $600 \mathrm{~nm}$ and the fluorescence emission spectra were collected from 605 to 700 $\mathrm{nm}$. Fluorimetric measurements were performed in $2 \mathrm{ml}$ quartz cuvettes in a SLM model 4800 fluorimeter (SLM Instruments, Urbana, IL) using a vertically polarized light beam from Hannovia 200-W mercury/xenon arc obtained with a Glan-Thompson polarizer (4-nm excitation and emission slits). To determine the $\mathrm{CrV}$ dissociation constants $\left(\mathrm{K}_{\mathrm{D}}\right)$, the values of $\mathrm{CrV}$ maximum fluorescence emission were plotted as a function of the logarithmic CrV concentrations (M). The resulting sigmoid curve was fitted to the Boltzmann function and $\mathrm{K}_{\mathrm{D}}$ was calculated.

\section{Electrophysiological experiments}

HEK293 cells expressing muscle or neuronal nAChRs were used for single-channel measurements two days after transfection. Single-channel recordings were performed in the cell-attached patch-clamp configuration at room temperature $\left(20^{\circ} \mathrm{C}\right)$ and at $-70 \mathrm{mV}$ of membrane potential. The bath and pipette solutions contained $142 \mathrm{mM} \mathrm{KCl}, 5.4 \mathrm{mM} \mathrm{NaCl}, 1.8$ $\mathrm{mM} \mathrm{CaCl} 2,1.7 \mathrm{mM} \mathrm{MgCl}_{2}$, and $10 \mathrm{mM} \mathrm{HEPES} \mathrm{(pH} \mathrm{7.4).} \mathrm{Either} \mathrm{ACh} \mathrm{or} \mathrm{the} \mathrm{tested} \mathrm{compounds}$ 
Molecular Pharmacology Fast Forward. Published on December 30, 2021 as DOI: 10.1124/molpharm.121.000415

This article has not been copyedited and formatted. The final version may differ from this version.

(pyrrolidine, theophylline or caffeine analogs $7-11$ ) were added to the pipette solution. Singlechannel currents were recorded using an Axopatch 200B patch-clamp amplifier (Molecular Devices), digitized at $200 \mathrm{kHz}$ and low-pass filtered at a cutoff frequency of $10 \mathrm{kHz}$ using a computer interface Instrutech ITC-18 (HEKA Instruments Inc.). Single-channel events were idealized by the half amplitude threshold criterion using the program QuB 2.0.0.28 (www.qub.buffalo.edu) with a digital low-pass filter at $9 \mathrm{kHz}$ for muscle and $\alpha 7 \mathrm{nAChR}$ recordings, or $3 \mathrm{kHz}$ for a7 recordings obtained in the presence of PNU. The open and closed durations were estimated from the idealized recordings by the maximum interval likelihood (MIL) function in QuB (Qin et al., 1996) with a dead time of $0.03 \mathrm{~ms}$ for muscle, or $0.1 \mathrm{~ms}$ for $\alpha 7$ receptor. The analysis was performed on the basis of a kinetic model whose probability density function curves properly described the corresponding histograms following the maximum likelihood criteria. For muscle nAChR, the best fitting was obtained with the classical kinetic model previously reported (Bouzat et al., 1994; Corradi et al., 2007). For a7 recordings, the analysis was performed by sequentially adding an open and/or closed state to a starting $\mathrm{C} \leftrightarrow \mathrm{O}$ model until it properly describes the corresponding duration histograms (Fabiani et al., 2018; Lasala et al., 2019). In general, for $\alpha 7$ recordings obtained in the presence of ACh or each of the testing compounds plus PNU, the best description was obtained when the model contained five or six closed states and two or three open states, similar to that previously described (Fabiani et al., 2018; Lasala et al., 2019). Clusters were identified as a series of closely separated openings preceded and followed by closings longer than a critical duration. Critical closed times were calculated by MIL between each closed component. Typically, critical time between the second and third closed components for muscle $(\sim 15 \mathrm{~ms})$ and between the third and fourth closed components for $\alpha 7$ nAChRs $(\sim 60 \mathrm{~ms})$ were selected in QuB to chop the idealized data and create a sub-data set that only contained clusters to define mean cluster duration and open probability within clusters (Popen). Popen within clusters was determined by calculating the mean fraction of time that the channel is open within a cluster.

\section{Molecular modeling}

Homology models of the extracellular domain of the mouse $\alpha 1 / \delta$ and $\alpha 1 / \varepsilon n A C h R$ interfaces were created using as template either the structure of the chimera $\alpha$ 7/AChBP which contains the loop C partially closed and which was crystalized with the partial agonist lobeline 
Molecular Pharmacology Fast Forward. Published on December 30, 2021 as DOI: 10.1124/molpharm.121.000415

This article has not been copyedited and formatted. The final version may differ from this version.

(PDB code 5AFM), or the structure of the human $\alpha 4 \beta 2$ nicotinic receptor in complex with nicotine, which contains the loop C closed (PDB code 5KXI, Morales-Perez et al., 2016). The amino acid sequences were aligned using ClustalW (http://www.ebi.ac.uk/Tools/msa/clustalw2/) and modeling was performed using Modeller 9.19 (Sali et al., 1995). Ten models were generated for each interface, of which the one with the lowest energy, calculated by Modeller as DOPE score (Shen and Sali, 2006), and the smallest percentage of amino acids in the disallowed region of the Ramachandran plot, obtained with Procheck (Laskowski et al., 1993), was selected for docking studies.

\section{Molecular docking}

For molecular docking we used the modeled mouse nAChR interfaces and the human AChE structure obtained from the PDB Data Bank (PDB code 4EY7, Cheung et al., 2012). Ligands were designed with Avogadro 1.2.0 and docked using AutoDock4.2 (Morris et al., 2009) The grid was defined around the orthosteric binding site for the nAChR models, and in the CAS/PAS site for the AChE structure. A hundred genetic algorithm runs were performed for each condition. Clustering of the results was done with AutoDock on the basis of a root-meansquare deviation cut-off of $2.0 \AA$. To evaluate the ability of each receptor to bind agonist, we compared the best binding energy (BBE) and the frequency of conformations that bind the agonist in the correct orientation in the binding pocket. Docking results were corroborated in at least three different procedures, and the most representative docking result was plotted with Discovery Studio Visualizer 2021 (Dassault Systèmes BIOVIA Corp, San Diego, USA).

\section{Data analysis}

In electrophysiological experiments comparison of two mean values were performed through unpaired Student's $t$ test whereas in fluorescence experiments comparison of more than two mean values were realized by analysis of variance (randomized one-way ANOVA), followed by post hoc test analysis of multiple comparisons Bonferroni. Differences were considered significant at $p<0.05$ and highly significant at $p<0.01$. In the case of $n=3$, the data were considered if the coefficient of variation (standard deviation / mean) was $<0.1$. 
Molecular Pharmacology Fast Forward. Published on December 30, 2021 as DOI: 10.1124/molpharm.121.000415 This article has not been copyedited and formatted. The final version may differ from this version. 
Molecular Pharmacology Fast Forward. Published on December 30, 2021 as DOI: 10.1124/molpharm.121.000415

This article has not been copyedited and formatted. The final version may differ from this version.

\section{RESULTS}

\section{Synthesis of caffeine analogs}

In the present work we focused on obtaining caffeine derivatives that could enhance cholinergic transmission with greater potency and efficacy than the lead compound. In order to potentiate caffeine activity, we combined two molecular entities, caffeine and nicotine, which have the same molecular targets (Figure 1). Nicotine, the principal alkaloid of tobacco plant, is an agonist of both neuronal and muscle nAChR (Akk and Auerbach, 1999; Fu et al., 2009; Carlson and Kraus, 2020) and also behaves as an inhibitor of the AChE (ljomone and Nwoha, 2015). It is a bicyclic molecule formed by a $\mathrm{N}$-methyl substituted pyrrolidine, protonated at physiological $\mathrm{pH}$, mimicking the quaternary ammonium of the $\mathrm{ACh}$, and a pyridine group with high electron density, mimicking the acetic group of the ACh. Along with the well-known harmful effects attributed to nicotine (Mishra et al., 2015; Mackenbach et al., 2017), some beneficial health effects were also described, mainly in memory and cognition processes (Jarvik, 1991; Rusted et al., 2005; Alhowail, 2012; Barreto et al., 2015; Gandelman et al., 2018), and some studies suggested that it could be useful for the treatment of AD (Srivareerat et al., 2009; Guo et al., 2015). To synthetize caffeine analogs, we used theophylline, a structure similar to caffeine but without the methyl group in position N-7. A pyrrolidine group, which is present in nicotine structure, was connected to N-7 of theophylline by means of a methylene chain with different length. This allowed us to obtain five compounds (from 3 to 7 methylene groups, referred as compounds 7 to 11 , respectively) (Figure 1).

-------- Figure 1 ----------

The general synthesis for the novel compounds 7-11 is depicted in Scheme 1. In a first step, the reaction between theophylline, $\mathbf{1}$, with the corresponding dibromoalkane in $\mathrm{K}_{2} \mathrm{CO}_{3} / \mathrm{dry}$ DMF, was carried out to offer intermediates 2-6 in moderate yields which presented a side chain of variable length (3 to 7 methylenes). The reaction was carried out in a microwave reactor under the following conditions: $150 \mathrm{~W}, 100^{\circ} \mathrm{C}, 10$ minutes. Compounds 2-6 were subsequentely treated with pyrrolidine in dry DMF, also in a MW assisted reaction (150 watts, $100^{\circ} \mathrm{C}, 5-12$ minutes), to obtain caffeine derivatives 7-11 with good yields (Scheme 1). 
Molecular Pharmacology Fast Forward. Published on December 30, 2021 as DOI: 10.1124/molpharm.121.000415

This article has not been copyedited and formatted. The final version may differ from this version.

\section{Inhibition of acetylcholinesterase by caffeine analogs}

The ability of caffeine derivatives to inhibit the AChE was analyzed and compared with that of the natural alkaloid, caffeine, and of their chemical precursors, theophylline and pyrrolidine.

We initially analyzed the inhibition of AChE activity in the presence of theophylline or pyrrolidine. We observed that pyrrolidine did not affect AChE activity at any concentration tested $(50-500 \mu \mathrm{M})$. On the other hand, theophylline inhibited the enzymatic activity, similar to that we reported for caffeine but with about one fifth the potency (Table 1). As a reference compound we analyzed the inhibition of AChE activity by tacrine, a potent AChE inhibitor (Biscussi et al., 2020).

Based on the $\mathrm{IC}_{50}$ values shown in Table 1, the potency of each compound was higher than theophylline, pyrrolidine, and caffeine. The $\mathrm{IC}_{50}$ values for compounds 7 and 11 were about 8.5- and 2150-fold, respectively, lower than for theophylline, which suggested that the length of the linker ( $\mathrm{n}$ in Scheme 1), that connects theophylline with pyrrolidine, is crucial for the inhibition of the enzyme.

Table 1

\section{Muscle nicotinic acetylcholine receptor activation by caffeine derivatives}

Given that caffeine acts as a partial agonist and an open-channel blocker of the nAChR (Fabiani et al., 2018) we here analyzed the effect of caffeine analogs on the muscle nAChR using the patch-clamp technique. In the presence of $30 \mu \mathrm{M} A C h$ receptor activation was observed as events of $5.2 \pm 0.6 \mathrm{pA}$ (at $-70 \mathrm{mV}$ of membrane potential) grouped in clusters of $140 \pm 70$ ms with a Popen of $0.4 \pm 0.1$ (Figure 2). In the presence of either compounds 7-11 or their corresponding precursors (theophylline and pyrrolidine), single-channel events were observed, thus indicating that these drugs act as muscle nAChR agonists (Figure 2).

Figure 2 
To study the kinetics of muscle nAChR activation in the presence of each compound, we recorded single-channel events at a range of concentrations from $0.01 \mathrm{pM}$ to $30 \mu \mathrm{M}$. For all the synthetic analogs, receptor activation was elicited at drug concentrations (about 0.01-0.1 pM) lower than that we previously reported for caffeine $(10 \mu \mathrm{M}$, Fabiani et al., 2018). At all concentrations of all compounds, nAChR activation was elicited as isolated openings without the ability to coalesce in clusters, as shown in the example of compound 9 (Figure 3).

After idealization we obtained the corresponding open and closed-duration histograms. For ACh, open time histograms were described by two components whose durations and relative areas were similar to those reported previously (Bouzat et al., 2000; Corradi et al., 2007). Closed time histograms were described by three or four components, the two briefest corresponding to closings within clusters.

For compound 9, the open duration remained constant at concentrations lower than 30 $\mu \mathrm{M}$ (Figure 3). The mean durations for the longest open component were $1.36 \pm 0.28 \mathrm{~ms}$ for 30 $\mu \mathrm{M} \mathrm{ACh}(n=8)$, and $1.26 \pm 0.09 \mathrm{~ms}(\mathrm{n}=17)$ for compound 9 at $0.1-10 \mu \mathrm{M}(\mathrm{p}=0.13$; comparison of mean values was performed using Student $t$ test). At compound 9 concentrations equal or higher than $30 \mu \mathrm{M}$, the open duration was reduced as shown in Figure 3. The mean open time was $0.52 \pm 0.01 \mathrm{~ms}(n=3)$, which was different from that obtained for $30 \mu \mathrm{M} \mathrm{ACh}(n=8)$, $(p=0.00036$; comparison of mean values was performed using Student $t$ test). This reduction in the mean open time may suggest that compound 9 behaves also as a muscle nAChR openchannel blocker, similarly to that we previously reported for caffeine (Fabiani et al., 2018).

-------- Figure 3

All these results demonstrate that the synthetized compounds behave as partial agonists of the muscle nAChR with greater potency than caffeine.

\section{Neuronal nicotinic acetylcholine receptor activation by caffeine derivatives}

To determine if caffeine derivatives can also activate neuronal nAChRs, we performed complementary experiments to study the effect of compound 9 on the neuronal human $\alpha 7$ nAChR. 
Molecular Pharmacology Fast Forward. Published on December 30, 2021 as DOI: 10.1124/molpharm.121.000415

This article has not been copyedited and formatted. The final version may differ from this version.

When $\alpha 7$ nAChR was activated by $100 \mu \mathrm{M}$ ACh, single-channel events appeared as brief isolated openings with a maximum amplitude of about $10 \mathrm{pA}$ (at $-70 \mathrm{mV}$ of membrane potential) as reported previously (Figure 4, Bouzat et al., 2008). Compound 9 at 10 or $100 \mu \mathrm{M}$, in the absence of $\mathrm{ACh}$, elicited the typical brief and isolated $\alpha 7$ channel openings (Figure 4). To further confirm that the observed openings were due to $\alpha 7$ activation, we performed singlechannel recordings in the presence of PNU-120596.

PNU-120596 is a type II positive allosteric modulator (PAM) of $\alpha 7$ nAChR, which enhances the probability of agonist-elicited channel opening and agonist-induced open-channel durations and also reduces desensitization. In the absence of an agonist, PNU-120596 cannot induce channel activation (Hurst et al., 2005, DaCosta et al., 2011, Bouzat et al., 2018). It has been extensively used as a tool to reveal $\alpha 7$ channel activity because it increases open probability and produces activation in long clusters at the single-channel level (Lasala et al., 2019). Thus, in the presence of $100 \mu \mathrm{M}$ ACh and $1 \mu \mathrm{M}$ PNU $\alpha 7$ activation appeared as long clusters of about $3065 \pm 1728 \mathrm{~ms}$, similarly to that previously reported (daCosta et al., 2011).

In the presence of $10 \mu \mathrm{M}$ compound 9 and $1 \mu \mathrm{M} \mathrm{PNU}$, the expected long clusters of openings were readily detected, with a mean cluster duration of $2629 \pm 1615 \mathrm{~ms}(n=8)$, thus confirming that this compound is an agonist of $\alpha 7 \mathrm{nAChR}$ (Figure 4). Clusters showed a lower open probability compared to that obtained in the presence of ACh $(0.61 \pm 0.02(n=8)$ and 0.91 $\pm 0.03(n=6)$, respectively, $p=0.00095$, comparison of mean values was performed using Student $t$ test), (Figure 4), which indicates that this compound activates $\alpha 7$ receptors with lower efficacy than ACh, or with the same efficacy but also produces additional block.

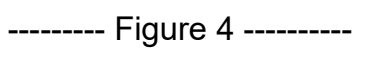

Given that we previously demonstrated that caffeine activates $\alpha 7$ at concentrations higher than $300 \mu \mathrm{M}$ in the absence of PNU (Fabiani et al., 2018), our results confirm that compound $\mathbf{9}$, as a representative of all caffeine derivatives, behaves as an $\alpha 7$ agonist with higher potency than caffeine.

\section{nAChR conformational changes induced by caffeine analogs}


Molecular Pharmacology Fast Forward. Published on December 30, 2021 as DOI: 10.1124/molpharm.121.000415

This article has not been copyedited and formatted. The final version may differ from this version.

Since we previously demonstrated that caffeine behaves both as partial agonist and negative modulator of nAChRs (Fabiani et al., 2018) and that this behavior correlates with distinct nAChR conformational states, we here extended our study to the conformational states of the nAChR in the presence of theophylline, pyrrolidine and compounds $7-11$. To this end, we used the fluorescence probe crystal violet, an open channel blocker of the nAChR, which presents a higher affinity for the desensitized (D) state with respect to the resting (R) one (Lurtz and Pedersen, 1999). Thus, in this experiment we studied the nAChR under two different situations: i) the nAChR in the absence of carb, to observe if the analogs induce any conformational change, and ii) the nAChR in the presence of desensitizing concentrations of carb, to check if the compounds alter the response of $n A C h R$ to carb. The difference between the $K_{D}$ values obtained with a sample before and after incubation with the agonist carb is not only directly indicative of $\mathrm{nAChR}$ conformational changes but also indirectly indicative of $\mathrm{nAChR}$ functionality (Fabiani et al., 2018).

The incubation of nAChR-rich membranes from $T$. californica with theophylline at low $(n=4)$ and high $(n=4)$ concentrations induced no changes on the conformational state of the $n A C h R: K_{D}$ values in the absence and presence of carb were similar to the $K_{D}$ values obtained from a control condition in the absence $(n=8)$ and presence $(n=8)$ of carb, respectively (Figure 5). In contrast, the presence of pyrrolidine at low $(n=4)$ and high $(n=4)$ concentrations induced changes on the $\mathrm{nAChR}$ conformational state at concentrations of $200 \mu \mathrm{M}$ or higher. Under these conditions, the $K_{D}$ values obtained in the absence of carb were close to the ones obtained for the $\mathrm{nAChR}$ in the desensitized state, suggesting that high concentrations of pyrrolidine lead to receptor desensitization (Figure 5).

-------- Figure 5 ---------

To explore if the activation of the nAChR could be correlated with its conformational changes, we incubated nAChR-rich membranes from $T$. californica with increasing concentrations (from $0.01 \mathrm{pM}$ to $400 \mu \mathrm{M}$ ) of compounds 7-11 in the absence and in the presence of carb (Figure 6). We observed that in the presence of carb and the analogs, nAChR desensitization occurred and the $K_{D}$ values were similar in all cases. In the absence of carb, different results were observed for the synthetic compounds. When membranes were incubated 
Molecular Pharmacology Fast Forward. Published on December 30, 2021 as DOI: 10.1124/molpharm.121.000415

This article has not been copyedited and formatted. The final version may differ from this version.

with compound $7(n=4)$ and $11(n=3)$ no changes were observed even at high concentrations. Under these conditions, the $K_{D}$ values were similar to those obtained in the absence of carb in the control condition, which corresponds to the resting state (Figure 6). With respect to compound $8(n=3)$, high concentrations $(200 \mu \mathrm{M})$ were needed to provoke a conformational change of the receptor, being this new conformation in between a resting and a desensitized state. When $T$. californica membranes were incubated with compounds $9(n=4)$ or $10(n=4)$ a decrease in the $K_{D}$ values was observed. With these compounds, the $K_{D}$ values obtained at all the tested concentrations were the same as the ones obtained in the presence of carb (Figure 6). Thus, based on our observations, compounds 9 and 10 provoke receptor desensitization even at very low concentrations $(0.01 \mathrm{pM})$.

------- Figure 6 ---------

\section{Binding modes of caffeine derivatives into the AChE and nAChR}

To test potential interactions that each compound can make with the AChE and the $\mathrm{nAChR}$, we performed molecular docking studies. We first analyzed the interaction of each compound on the AChE using the structure 4EY7.pdb crystalized in complex with donepezil (Supplementary Figure S1, Cheung et al., 2012). The AChE structure shows donepezil bound to the active site with its benzyl group located in the CAS and the dimethoxyindanone ring placed in the PAS. Therefore, for our docking studies, we limited the grid dimensions to cover the CAS and PAS regions (CAS/PAS site, Figure 7A).

We first docked donepezil in the CAS/PAS site as an internal control. The main conformation showed a BBE of about $-11.88 \mathrm{Kcal} / \mathrm{mol}$ and similar interactions to those reported in the crystal structure (Figure 7B, Table 2, Cheung et al., 2012). We observed a cation- $\pi$ interaction between the positive charge of the piperidine group of donepezil and residues D74 and $Y 337, \pi-\pi$ staking between the benzyl group and residues $W 86$ and $H 447$, and between the dimethoxyindanone group and residues W286 and $\mathrm{Y} 341$, and $\mathrm{H}$-bond between the dimethoxyindanone group and residue F295 (Figure 7B). Most of these interactions were previously reported as critical for AChE inhibition (Cheung et al., 2012; deAlmeida et al., 2018). 
Molecular Pharmacology Fast Forward. Published on December 30, 2021 as DOI: 10.1124/molpharm.121.000415

This article has not been copyedited and formatted. The final version may differ from this version.

We then studied the orientation of pyrrolidine and theophylline in the CAS/PAS site of the human AChE. Our results showed that these molecules can bind in this active site with different orientations and interactions (Figure 7C and 7D, and Table 2). We observed that the main conformation for theophylline was located close to the PAS site, making $\pi-\pi$ interactions with W286 and Y341, m-alkyl interactions with Y72, L289, V294, F297 and F338, hydrophobic interactions with R296, and H-bonds with S293, F295 and R296 (Figure 7C). The BBE observed for this conformation was about $-5.3 \mathrm{Kcal} / \mathrm{mol}$. Pyrrolidine only showed, instead, cation- $\pi$ interaction with residues W86 and a salt bridge with E202, both residues from the CAS, with a BBE of about $-4.8 \mathrm{Kcal} / \mathrm{mol}$ (Figure 7D). All these observations are in line with our experimental results and suggest that theophylline can inhibit the AChE due to the number and type of interactions it could make in the PAS.

Finally, we extended our docking study to caffeine derivatives. We observed that the main cluster for each compound showed a similar location to that observed for donepezil. All compounds were placed in the CAS/PAS site with the pyrrolidine group orientated towards the CAS and the theophylline group interacting with residues in the PAS (Figure 7E and 7F) with their BBE ranging from -8.56 and $-9.79 \mathrm{Kcal} / \mathrm{mol}$ from compound 7 and 11 , respectively (Table 2). The pyrrolidine group showed the ability to interact with $\mathrm{H} 447$ which belongs to the ester subsite (crucial for the catalytic action of the enzyme) and make cation- $\pi$ interaction with W86 and a salt bridge with D74 or E202 of the anionic subsite, similarly to that observed when pyrrolidine was docked alone (Figure 7D). As it was expected, the theophylline group was placed mainly in the PAS and showed an increase in the number of residue interactions with the increase in the linker length (Table 2). Thus, while compound 7 showed $\pi-\pi$ interactions with W286 and F297, m-alkyl interactions with Y72 and V294, and H-bonds with F295 and Y341, compound 11 showed $\pi-\pi$ interactions with Y124, W286, F295 and Y341, $\pi$-alkyl interactions with Y72, W286, V294, and Y341, and H-bonds with Y124, F295 and Y341 (Figure 7E, 7F and Table 2). 
Molecular Pharmacology Fast Forward. Published on December 30, 2021 as DOI: 10.1124/molpharm.121.000415

This article has not been copyedited and formatted. The final version may differ from this version.

Thus, our docking results suggest that each compound can bind into the CAS/PAS site and interact with residues that were previously reported as key for AChE modulation (Quinn, 1987; Branduardi et al., 2005; Johnson and Moore, 2006). From the docking of each compound, we observed that the pyrrolidine group is important to stabilize and better orientate the theophylline group in the PAS. With the increase in the length of the linker chain, we observed an increase in the number of interactions between the theophylline group and key residues from the PAS, which suggests an improvement in the inhibition ability, which is in line with our experimental observations.

Table 2

To extend our knowledge about the molecular interactions between each synthetic compound and the nAChR, we performed molecular docking studies. To this end, we modeled the extracellular domain of two adjacent subunits corresponding to the interfaces $\alpha 1 / \delta$ and $\alpha 1 / \varepsilon$ for the mouse muscle nAChR. Three loops from the a subunit (loops A-C) form the principal face and provide the aromatic residues Y93, W149, Y190 and 198, which stabilize the ammonium of the agonist (ACh or nicotine) by means of cation-m and $\mathrm{H}$-bond interactions (Xiu et al., 2009). The subunit that forms the complementary face contributes with loops $D, E$ and $F$, from which residues W55 and L119 have been reported to contribute to cation-m and/or H-bond interaction with the agonist, respectively (Karlin, 2002; Blum et al., 2010).

After binding of a full agonist, loop $\mathrm{C}$ closes to cover the binding pocket in a mechanism known as "capping" (Hansen et al., 2005). It was suggested that some partial agonists are unable to provoke a complete closure of loop C, which could be responsible for the partial channel response (Hibbs et al., 2009).

Since all compounds we tested in this work behave as partial agonists for the muscle nAChR, we evaluated their molecular interactions with two models, one with loop $C$ in a closed conformation (named as "capped model"), and other with loop C in a partially closed conformation (named as "partially capped model"). With both models, we then performed molecular dockings for each compound (Supplementary Figure S2).

As an initial control, we docked ACh in both interfaces ( $\alpha 1 / \delta$ and $\alpha 1 / \varepsilon)$ into the orthosteric binding site of the capped model (Figure 8B). We observed that the most frequent 
Molecular Pharmacology Fast Forward. Published on December 30, 2021 as DOI: 10.1124/molpharm.121.000415

This article has not been copyedited and formatted. The final version may differ from this version.

conformation showed the lowest BBE (about $-5.0 \mathrm{Kcal} / \mathrm{mol})$. In this conformation, ACh adopted a similar orientation to that reported previously from the binding protein crystal structure (Olsen et al., 2014). ACh docked with its quaternary amine orientated to the lower part of the cleft, where it has the potential to form cation- $\pi$ interactions with the above-mentioned aromatic residues from the principal face, and cation- $\pi$ with W55 and/or H-bond with L119, both from the complementary face (Figure 8B).

We subsequently performed the same docking study for pyrrolidine and theophylline. We observed that pyrrolidine bound into the orthosteric binding site and the most frequent conformation (and with the lowest BBE of about $-4.5 \mathrm{Kcal} / \mathrm{mol}$ ) showed the ability to make interactions with residues from the principal face but it lacked interactions with residues from the complementary face (Figure $8 \mathrm{C}$ ). In this conformation, the ammonium group of pyrrolidine, which is protonated at $\mathrm{pH}$ between 7.0-7.4, showed the potential to make a cation- $\pi$ and $\mathrm{H}$ bond interactions with W149, and a cation-m interaction with Y198 (Figure 8C). All these results were similar to those reported previously for choline, a muscle nAChR partial agonist (Bruhova and Auerbach, 2017). The lack of interactions with residues from the complementary face could be responsible for the partial response observed for pyrrolidine since interactions with residues W55 and L119 have been reported as relevant for channel activation (Blum et al., 2010; Hernando et al., 2012). When we carried out the same analysis for theophylline, we observed that none of the conformations was able to dock into the orthosteric binding site. Therefore, we used the $\alpha 1 / \delta$ and $\alpha 1 / \varepsilon$ partially capped models. From these studies, we observed that the most frequent conformation, which was also the one with the lowest BBE (about $-5.3 \mathrm{Kcal} / \mathrm{mol}$ ), showed the potential to interact with residues from the binding site (Figure 8D). In these models, theophylline showed the ability to form $\pi-\pi$ staking with W149 and Y190, $\pi$-alkyl with W149 and C192, and H-bonds with W149 and Y198 from the principal face (Figure 8D). This conformation also showed the ability to form m-alkyl with W55 and H-bond with L119, both residues from the complementary face (Figure 8D). 
We finally evaluated the ability of caffeine derivatives to bind into the orthosteric binding site of the nAChR. Based on the results we obtained with theophylline, we here carried out docking experiments with the partially capped models. We observed that all compounds were able to bind into the binding pocket, where the most stable conformation showed similar frequency (about 20\%) and BBE (about $-7.5 \mathrm{Kcal} / \mathrm{mol}$ ). In these conformations, each compound showed similar orientation, with the positive charge of the pyrrolidine group making cation- $\pi$ interaction with W149 and Y190, and H-bond with Y198, all residues from the principal face (Figure $8 \mathrm{E}$ and $8 \mathrm{~F}$ ). The theophylline group was found to face the lower part of the pocket and showed the ability to make $\pi-\pi$ stacking with W55, m-alkyl with W55 and P169, and H-bond with S38 or N126, all residues from the complementary face (Figure $8 \mathrm{E}$ and $8 \mathrm{~F}$ ). All these results suggest that compounds 7-11 could make interactions with residues from the nAChR orthosteric binding pocket, which are critical for receptor response. However, this was only observed when the loop $C$ was partially closed, which could be a plausible mechanism that explains why these compounds behave as partial agonists. 
Molecular Pharmacology Fast Forward. Published on December 30, 2021 as DOI: 10.1124/molpharm.121.000415

This article has not been copyedited and formatted. The final version may differ from this version.

\section{DISCUSSION}

$A D$ is the principal cause of dementia among the elderly. Nowadays there are still certain controversies about the causes and mechanisms of $A D$ and this is the reason why the development of new drugs for the treatment of this disease continues to be a great challenge (Dineley, 2007). The currently available medications, mainly inhibitors of the AChE, only ameliorate the symptoms in an early stage of the disease.

In a previous work, we postulated caffeine as an interesting molecule due to its potentiality to improve cholinergic transmission by a dual mechanism: inhibition of AChE and agonism of nAChRs (Fabiani et al., 2018). In this work we obtained 5 caffeine derivatives by connecting theophylline and pyrrolidine through a methylene chain of different lengths.

We demonstrated that theophylline, like caffeine, inhibits the AChE although it is less potent (Table 1). In contrast, pyrrolidine does not inhibit the AChE. We found that all derivatives inhibit the AChE with greater potency than caffeine, this effect being related to the length of the linker since compound 11 was the most potent, with an $\mathrm{IC}_{50}$ value two orders of magnitude higher than caffeine (Table 1). These results confirm that for AChE inhibition the presence of a substituent at N-7 in the theophylline structure is essential.

In order to analyze the binding interactions of these compounds with the AChE, we performed molecular docking studies. We worked with the structure of human AChE in complex with donepezil (PDB code 4EY7, Cheung et al., 2012). We first studied the location of theophylline and pyrrolidine and observed that while theophylline interacts mainly with residues from the PAS, pyrrolidine was docked in the CAS, without interaction with residues from the PAS, which could indicate that either the residues affected, or the binding energy are not the optimal to allow pyrrolidine to behave as an AChE inhibitor. The same results were found with respect to the synthetic analogs: the pyrrolidine group was docked in the CAS while the structure corresponding to the theophylline was docked in the PAS. Thus, caffeine derivatives interact with residues similar to donepezil, corresponding to both sites, CAS and PAS, which could explain their ability to inhibit AChE. The length of the methylene chain of caffeine derivatives impacts on their potency, probably by allowing a better location in both sites, which could explain why compound $\mathbf{1 1}$ showed the greatest AChE inhibition.

We then studied the effect of synthetic caffeine analogs on the nAChRs. Patch-clamp experiments showed that all compounds behaved as agonists of the muscle nAChR. Both 
Molecular Pharmacology Fast Forward. Published on December 30, 2021 as DOI: 10.1124/molpharm.121.000415

This article has not been copyedited and formatted. The final version may differ from this version.

chemical precursors behaved as partial agonists of the muscle receptor, showing an activation profile as isolated events. Caffeine analogs activated the muscle nAChR even at very low concentrations (picomolar range), which demonstrates that they behave as agonists with higher potency than caffeine (Fabiani et al., 2018). Based on our results, we confirmed that these compounds activate the muscle nAChR as isolated events without the ability to form clusters, even at high concentrations. Our results confirm that these compounds behave as potent partial agonists, similar to our observations from their precursors, theophylline and pyrrolidine, and that we reported previously for caffeine (Fabiani et al., 2018). To deepen our results, we obtained single-channel recordings from cells expressing the human $\alpha 7 \mathrm{nAChR}$ in the presence of compound 9. This compound, in the absence of PNU, activates $\alpha 7$ receptor at concentrations 10-fold lower than those we reported for caffeine (Fabiani et al., 2018). Thus, we confirmed that the synthetic compounds behaved as agonists of both muscle and neuronal $\alpha 7 \mathrm{nAChRs}$ with higher potency than caffeine.

We then studied the muscle nAChR conformational state in the presence of the compounds. A first striking result was that theophylline showed no ability to stabilize the receptor in a desensitized conformation (Figure 5), although, as stated above, it behaves as an agonist of the muscle nAChR (Figure 2). This result reinforces the importance of the N-7 substituent on account of the fact that theophylline and caffeine have different effects on the conformational state of the nAChR. On the other hand, and contrary to expectations based on the importance of both cyclic groups of the nicotine for full nAChR activation (Graton et al., 2003; Blum et al., 2010), pyrrolidine not only activated the muscle nAChR (Figure 2) but stabilized it in a desensitized conformational state (Figure 5). Caffeine derivatives showed different effects on the nAChR conformational states depending on the length of the methylene chain linker (Figure 6). While compounds $\mathbf{9}$ and $\mathbf{1 0}$ were able to desensitize the muscle nAChR, similarly to what was observed with pyrrolidine and previously reported for caffeine and carb (Fabiani et al., 2018), compounds 7, 8 and 11 behaved like theophylline, i.e. although by electrophysiological experiments we observed that they activated the muscle nAChR, CrV experiments confirmed that they did not stabilize the receptor in a desensitized conformation at all concentration ranges. It is probably that these compounds make different non-covalent interactions at the binding site which may result in diverse desensitized states, some more 
Molecular Pharmacology Fast Forward. Published on December 30, 2021 as DOI: 10.1124/molpharm.121.000415

This article has not been copyedited and formatted. The final version may differ from this version.

stable or deeper than others, and hence, in one case the receptor stabilizes in a desensitized state, and in the other it either returns rapidly to a resting state (Reitstetter et al., 1991) or does not arrive to this state at all. In all cases, the addition of carb after incubation with compounds 711 confirmed that the compounds did not alter the response of nAChR to agonist, indicating that they do not exert a main inhibitory effect as described before for QX 314 (channel blocker) or $\alpha$ bungarotoxin (competitive antagonist) (Fabiani et al., 2018).

To deepen our results, we performed molecular docking experiments. The orthosteric agonist binding sites are in the extracellular domain at the interface between two subunits. These sites are formed by 6 loops distributed on two faces: a principal face ( $\alpha$ subunit), formed by loops $A, B$ and $C$ and a complementary face formed by loops $D, E$ and $F$ (non- $\alpha$ subunit). Following agonist binding, loop $\mathrm{C}$ closes to cover the binding site in a mechanism known as capping, that was suggested as crucial for channel gating (Hansen et al., 2005; Mukhtasimova et al., 2009). Different structures were solved in the absence or in the presence of ligands. They show that loop $\mathrm{C}$ is in an uncapped conformation in the absence of ligand or in the presence of antagonists (Hansen et al., 2005; Billen et al., 2012). When a partial agonist is bound, loop C adopts a partially capped conformation, which was suggested as responsible for the partial receptor response (Hibbs et al., 2009; Billen et al., 2012; Spurny et al., 2015).

We generated two homology models for each of the orthosteric binding sites for the mouse muscle nAChR, one model with loop $C$ in a capped conformation and one with loop $C$ in a partially capped conformation. Pyrrolidine mainly interacts with the capped model. The main conformation was placed towards the principal face of the binding pocket and it did not show interactions with residues from the complementary face, similar to choline, a classical muscle nAChR partial agonist (Bruhova and Auerbach, 2017). The lack of interactions with residues from the complementary face could be responsible for the partial response observed for pyrrolidine. Theophylline could interact with the orthosteric binding site only in the partially capped model showing different interactions with residues from the principal and complementary face. Since at pH between 7.0-7.4 theophylline is mainly in the un-protonated form, it could not form cation-m interactions with residues from the binding site. Therefore, the partially capped conformation of the receptor and the lack of cation-m interactions between theophylline and residues from the binding site are plausible explanations for the partial 
Molecular Pharmacology Fast Forward. Published on December 30, 2021 as DOI: 10.1124/molpharm.121.000415

This article has not been copyedited and formatted. The final version may differ from this version.

response observed.

Similarly to theophylline, all compounds docked into the orthosteric binding site only when the loop C was partially closed. Unlike what we observed from docking studies with AChE, compounds 7-11 showed similar conformations, which suggests that the length of the linker was not a relevant characteristic for $\mathrm{nAChR}$ activation. The theophylline group was placed in the lower part of the binding pocket making interactions with residues from the complementary face. Therefore, in spite of their ability to make cation- $\pi$ interactions with residues from the principal face, the partially capped conformation and the type of interactions with residues from the complementary face seem to be possible mechanisms that explain the action as partial agonist for the synthetized compounds.

In this work we synthetized five novel hybrid-compounds, analogs of the caffeine, which can inhibit the AChE and activate both muscle and $\alpha 7$ nAChRs with higher potency than caffeine. Based on our results, caffeine analogs can be divided into two groups. Although all of them activate nAChRs, some of them conduct the receptor to a desensitized and agonistrefracting state, while others make the receptor to quickly return to a resting, agonist-responding state. The different effect depends on the length of the linker between theophylline and pyrrolidine. This result is a novel structure-activity relationship that emerge in distinct hybridanalogues. The fact that such a small difference in the structure produces a different effect on $\mathrm{nAChR}$ activity while maintaining the AChE inhibitory effect offers novel and very interesting options in drug design, giving valuable tools to transform the search of new drugs from random screening to a detailed rational drug design. The choice of a particular group of compounds will depend on the desired specific biological effect. For the treatment of $A D$, a pathology in which there is an important loss of cholinergic neurons, the fact that some analogs behave as potent agonists of the nAChRs avoiding receptor desensitization appears to be a promising therapy for the enhancing of cholinergic transmission. From the nAChR-non desensitizing group, compound $\mathbf{1 1}$ is the most interesting analog for further studies since it inhibits AChE with the highest potency and activates the nAChRs in the picomolar range without inducing receptor desensitization. 
Molecular Pharmacology Fast Forward. Published on December 30, 2021 as DOI: 10.1124/molpharm.121.000415 This article has not been copyedited and formatted. The final version may differ from this version. 
Molecular Pharmacology Fast Forward. Published on December 30, 2021 as DOI: 10.1124/molpharm.121.000415

This article has not been copyedited and formatted. The final version may differ from this version.

\section{ACKNOWLEDGMENTS}

Esp. María de la Paz Guillon, Mg. Alicia B. Hernandez, Esp. Liliana A. García. Math Department, Universidad Nacional del Sur, Bahía Blanca, Argentina.

\section{AUTHORSHIP CONTRIBUTIONS}

Participated in research design: Fabiani, Biscussi, Murray, Corradi and Antollini.

Design and synthesis of chemical entities: Biscussi and Murray.

Conducted experiments: Fabiani, Biscussi and Munafó.

Performed data analysis: Fabiani, Biscussi, Murray, Corradi and Antollini

Contributed to the writing of the manuscript: Fabiani, Corradi and Antollini. 
Molecular Pharmacology Fast Forward. Published on December 30, 2021 as DOI: 10.1124/molpharm.121.000415

This article has not been copyedited and formatted. The final version may differ from this version.

\section{REFERENCES}

Akk G and Auerbach A (1999) Activation of muscle nicotinic acetylcholine receptor channels by nicotinic and muscarinic agonists. Br. J. Pharmacol. 128:1467-176.

Alhowail A (2012) Molecular insights into the benefits of nicotine on memory and cognition. Mol. Med. Rep. 23:398.

Barrantes FJ (1982) Oligomeric forms of the membrane-bound acetylcholine receptor disclosed upon extraction of the Mr 43,000 nonreceptor peptide. J. Cell. Biol. 92:60-68.

Barreto GE, larkov A, Echeverria Moran V (2015) Beneficial effects of nicotine, cotinine and its metabolites as potential agents for Parkinson's disease. Front. Aging. Neurosci. 9:340.

Billen B, Spurny R, Brams M, van Elk R, Valera-Kummer S, Yakel JL, Voets T, Bertrand D, Smit AB, Ulens C (2012) Molecular actions of smoking cessation drugs at $\alpha 4 \beta 2$ nicotinic receptors defined in crystal structures of a homologous binding protein. Proc. Natl. Acad. Sci. USA. 109: 9173-9178.

Biscussi B, Richmond V, Baier CJ, Mañez PA, Murray AP (2020) Design and Microwave-Assisted Synthesis of Aza-Resveratrol Analogs with Potent Cholinesterase Inhibition. CNS. Neurol. Disord. Drug. Targets. 19: 630641.

Blum AP, Lester HA, Dougherty DA (2010) Nicotinic pharmacophore: the pyridine N of nicotine and carbonyl of acetylcholine hydrogen bond across a subunit interface to a backbone NH. Proc. Natl. Acad. Sci. USA. 107: 13206-13211.

Blum AP, Van Arnam EB, German LA, Lester HA (2013) Dougherty, D.A. Binding interactions with the complementary subunit of nicotinic receptors. J. Biol. Chem. 288:6991-6997.

Bouzat C, Barrantes F, Sine S (2000) Nicotinic receptor fourth transmembrane domain: hydrogen bonding by conserved threonine contributes to channel gating kinetics. J. Gen. Physiol. 115:663-672.

Bouzat C, Bartos M, Corradi J, Sine SM (2008) The interface between extracellular and transmembrane domains of homomeric Cys-loop receptors governs open-channel lifetime and rate of desensitization. J. Neurosci. 28: 7808-7819.

Bouzat, C.; Bren, N.; Sine, S.M. (1994) Structural basis of the different gating kinetics of fetal and adult acetylcholine receptors. Neuron. 13:1395-1402.

Branduardi D, Gervasio FL, Cavalli A, Recanatini M, Parrinello M (2005) The role of the peripheral anionic site and cation-pi interactions in the ligand penetration of the human AChE gorge. J. Am. Chem. Soc. 127:91479155.

Bruhova I and Auerbach A (2017) Molecular recognition at cholinergic synapses: acetylcholine versus choline. $J$ Physiol. 595: 1253-1261.

Carlson AB and Kraus GP (2020) Physiology, Cholinergic Receptors. NBK526134.

Cheung J, Rudolph MJ, Burshteyn F, Cassidy MS, Gary EN, Love J, Franklin, MC, Height JJ (2012) Structures of human acetylcholinesterase in complex with pharmacologically important ligands. J. Med. Chem. 55:1028210286.

Contestabile A (2011) The history of the cholinergic hypothesis. Behav. Brain. Res. 221:334-340.

Corradi J and Bouzat C (2016) Understanding the Bases of Function and Modulation of $\alpha 7$ Nicotinic Receptors: Implications for Drug Discovery. Mol. Pharmacol. 90: 288-299.

Corradi J, Spitzmaul G, De Rosa MJ, Costabel M, Bouzat C (2007) Role of pairwise interactions between M1 and M2 domains of the nicotinic receptor in channel gating. Biophys. J. 92:76-86.

Craig LA, Hong NS, McDonald RJ (2011) Revisiting the cholinergic hypothesis in the development of Alzheimer's disease. Neurosci. Biobehav. Rev. 35:1397-1409.

daCosta CJ, Sturgeon R, Hamouda AK, Blanton MP, Baenziger JE (2011) Structural characterization and agonist binding to human alpha4beta2 nicotinic receptors. Biochem. Biophys. Res. Commun. 407:456-460.

D'Andrea MR and Nagele RG (2006) Targeting the alpha 7 nicotinic acetylcholine receptor to reduce amyloid accumulation in Alzheimer's disease pyramidal neurons. Curr. Pharm. Des. 12:677-684. 
Molecular Pharmacology Fast Forward. Published on December 30, 2021 as DOI: 10.1124/molpharm.121.000415 This article has not been copyedited and formatted. The final version may differ from this version.

Dani JA and Bertrand D (2007) Nicotinic acetylcholine receptors and nicotinic cholinergic mechanisms of the central nervous system. Annu Rev Pharmacol Toxicol. 47:699-729.

Davies P and Maloney AJ (1976) Selective loss of central cholinergic neurons in Alzheimer's disease. Lancet. 2:1403.

de Almeida J, Figueiro M, Pereira Almeida W, Tomich de Paula da Silva CH (2018) Discovery of novel dual acetylcholinesterase inhibitors with antifibrillogenic activity related to Alzheimer's disease. Future. Med. Chem. 10: $1037-1053$.

Dineley KT (2007) Beta-amyloid peptide--nicotinic acetylcholine receptor interaction: the two faces of health and disease. Front. Biosci. 12:5030-5038.

Ellman GL, Courtney KD, Andres V (1961) Feather-stone, R.M. A new and rapid colorimetric determination of acetylcholinesterase activity. Biochem. Pharmacol. 7:88-95.

Fabiani C, Murray AP, Corradi J, Antollini, S.S. A novel pharmacological activity of caffeine in the cholinergic system. Neuropharmacology. 135:464-473.

Fu XW, Lindstrom J, Spindel ER (2009) Nicotine activates and up-regulates nicotinic acetylcholine receptors in bronchial epithelial cells. Am. J. Respir. Cell. Mol. Biol. 41:93-99.

Gandelman JA, Newhouse P, Taylor WD (2018) Nicotine and networks: Potential for enhancement of mood and cognition in late-life depression. Neurosci. Biobehav. Rev. 84:289-298.

Graton J, Berthelot M, Gal JF, Laurence C, Lebreton J.; Le Questel, J.Y.; Maria, P.C.; Robins, R. (2003) The nicotinic pharmacophore: thermodynamics of the hydrogen-bonding complexation of nicotine, nornicotine, and models. J. Org. Chem. 68:8208-8221.

Guo CN, Sun L, Liu GL, Zhao SJ, Liu WW, Zhao YB (2015) Protective effect of nicotine on the cultured rat basal forebrain neurons damaged by $\beta$-Amyloid $(A \beta) 25-35$ protein cytotoxicity. Eur. Rev. Med. Pharmacol. Sci. 19:2964-2672.

Hampel H, Mesulam MM, Cuello AC, Farlow MR, Giacobini E, Grossberg GT, Khachaturian AS, Vergallo A, Cavedo E, Snyder PJ, Khachaturian ZS (2018) The cholinergic system in the pathophysiology and treatment of Alzheimer's disease. Brain. 141:1917-1933.

Hansen SB, Sulzenbacher G, Huxford T, Marchot P, Taylor P, Bourne Y (2005) Structures of Aplysia AChBP complexes with nicotinic agonists and antagonists reveal distinctive binding interfaces and conformations. EMBO. J. 24:3635-3646.

Hernando G, Bergé I, Rayes D, Bouzat C (2012) Contribution of subunits to Caenorhabditis elegans levamisolesensitive nicotinic receptor function. Mol. Pharmacol. 82:550-560.

Hibbs RE, Sulzenbacher G, Shi J, Talley TT, Conrod S, Kem WR, Taylor P, Marchot P, Bourne Y (2009) Structural determinants for interaction of partial agonists with acetylcholine binding protein and neuronal alpha7 nicotinic acetylcholine receptor. EMBO. J. 28:3040-3051.

ljomone OM and Nwoha PU (2015) Nicotine inhibits hippocampal and striatal acetylcholinesterase activities, and demonstrates dual action on adult neuronal proliferation and maturation. Pathophysiology. 22:231-239.

Inestrosa NC, Sagal JP, Colombres M (2005) Acetylcholinesterase interaction with Alzheimer amyloid beta. Subcell. Biochem. 38:299-317.

Jarvik ME (1991) Beneficial effects of nicotine. Br. J. Addict. 86:571-575.

Johnson G and Moore SW (2006) The peripheral anionic site of acetylcholinesterase: structure, functions and potential role in rational drug design. Curr. Pharm. Des. 12:217-225.

Karlin A (2002) Emerging structure of the nicotinic acetylcholine receptors. Nat. Rev. Neurosci. 3:102-114.

Karlin A and Akabas MH (1995) Toward a structural basis for the function of nicotinic acetylcholine receptors and their cousins. Neuron. 15:1231-1244.

Lasala M, Fabiani C, Corradi J, Antollini S, Bouzat C (2019) Molecular Modulation of Human a7 Nicotinic Receptor by Amyloid- $\beta$ Peptides. Front. Cell. Neurosci. 8:13-37.

Laskowski RA, Moss DS, Thornton JM (1983) Main-chain bond lengths and bond angles in protein structures. J. Mol. Biol. 231:1049-1067. 
Molecular Pharmacology Fast Forward. Published on December 30, 2021 as DOI: 10.1124/molpharm.121.000415 This article has not been copyedited and formatted. The final version may differ from this version.

Lurtz MM and Pedersen SE (1999) Aminotriarylmethane dyes are high-affinity noncompetitive antagonists of the nicotinic acetylcholine receptor. Mol. Pharmacol. 55:159-167.

Ma KG and Qian YH (2019) Alpha 7 nicotinic acetylcholine receptor and its effects on Alzheimer's disease. Neuropeptides. 73:96-106.

Mackenbach JP, Damhuis RAM, Been JV (2017) The effects of smoking on health: growth of knowledge reveals even grimmer picture. Br. J. Addict. 86:571-575.

Martorana A, Esposito Z, Koch G (2010) Beyond the cholinergic hypothesis: do current drugs work in Alzheimer's disease? CNS. Neurosci. Ther. 16:235-245.

McKay BE, Placzek AN, Dani JA (2007) Regulation of synaptic transmission and plasticity by neuronal nicotinic acetylcholine receptors. Biochem. Pharmacol. 74:1120-1133.

Mishra A, Chaturvedi P, Datta S, Sinukumar S, Joshi P, Garg A (2015) Harmful effects of nicotine. Indian J. Med. Pediatr. Oncol. 36:24-31.

Morales-Perez CL, Noviello CM, Hibbs RE (2016) X-ray structure of the human $\alpha 4 \beta 2$ nicotinic receptor. Nature. 538:411-415.

Morris GM, Huey R, Lindstrom W, Sanner MF, Belew RK, Goodsell DS, Olson AJ (2009) AutoDock4 and AutoDockTools4: Automated docking with selective receptor flexibility. J. Comput. Chem. 30:2785-2791.

Mukhtasimova N, Lee WY, Wang H, Sine SM (2009) Detection and trapping of intermediate states priming nicotinic receptor channel opening. Nature. 459:451-454.

Olsen JA, Balle T, Gajhede M, Ahring PK, Kastrup JS (2014) Molecular recognition of the neurotransmitter acetylcholine by an acetylcholine binding protein reveals determinants of binding to nicotinic acetylcholine receptors. PLoS. One. 9:e91232.

Paterson D and Nordberg A (2000) Neuronal nicotinic receptors in the human brain. Prog. Neurobiol. 61:75-111. DOI:10.1016/S0301-0082(99)00045-3

Perry EK, Tomlinson BE, Blessed G, Perry RH, Cross AJ, Crow TT (1981) Noradrenergic and cholinergic systems in senile dementia of Alzheimer type. Lancet. 2:149.

Pohanka M (2012) Alpha7 nicotinic acetylcholine receptor is a target in pharmacology and toxicology. Int. J. Mol. Sci. 13:2219-2238.

Qin F, Auerbach A, Sachs F (1996) Estimating single-channel kinetic parameters from idealized patch-clamp data containing missed events. Biophys. J. 70:264-280.

Quinn DM (1987) Acetylcholinesterase: enzyme structure, reaction dynamics, and virtual transition states. Chem. Rev. 87:955-979.

Reitstetter R, Lukas RJ, Gruener R (1990) Dependence of nicotinic acetylcholine receptor recovery from desensitization on the duration of agonist exposure. J. Pharmacol. Exp. Ther. 289:656-660.

Rusted JM, Trawley S, Heath J, Kettle G, Walker H (2005) Nicotine improves memory for delayed intentions. Psychopharmacology (Berl). 182:355-365.

Sali A (1995) Comparative protein modeling by satisfaction of spatial restraints. Mol Med Today. 1:270-277.

Selkoe D, Mandelkow E, Holtzman D (2012) Deciphering Alzheimer disease. Cold. Spring. Harb. Perspect. Med. 2:a011460.

Shen M and Sali A (2006) Statistical potential for assessment and prediction of protein structures. Protein. Sci. 15:2507-2524.

Singh M, Kaur M, Kukreja H, Chugh R, Silakari O, Singh D (2013) Acetylcholinesterase inhibitors as Alzheimer therapy: from nerve toxins to neuroprotection. Eur. J. Med. Chem. 70:165-188.

Spurny R, Debaveye S, Farinha A, Veys K, Vos AM, Gossas T, Atack J, Bertrand S, Bertrand D, Danielson UH, Tresadern G, Ulens C (2015) Molecular blueprint of allosteric binding sites in a homologue of the agonist-binding domain of the $\alpha 7$ nicotinic acetylcholine receptor. Proc. Natl. Acad. Sci. USA. 112:2543-2552.

Srivareerat M, Tran TT, Alzoubi KH, Alkadhi KA (2009) Chronic psychosocial stress exacerbates impairment of cognition and long-term potentiation in beta-amyloid rat model of Alzheimer's disease. Biol. Psychiatry. 65:918926. 
Molecular Pharmacology Fast Forward. Published on December 30, 2021 as DOI: 10.1124/molpharm.121.000415

This article has not been copyedited and formatted. The final version may differ from this version.

Whitehouse PJ and Au KS (1986) Cholinergic receptors in aging and Alzheimer's disease. Prog. Neuropsychopharmacol. Biol. Psychiatry. 10:665-676.

Xiu X, Puskar NL, Shanata JA, Lester HA, Dougherty DA (2009) Nicotine binding to brain receptors requires a strong cation-pi interaction. Nature. 458:534-537.

\section{FOOTNOTES}

${ }^{\dagger}$ This work has been supported by CONICET (Grant PIP 11220170100399C to SSA); Agencia Nacional de Promoción Científica y Tecnológica (ANPCyT) (Grant PICT 2017-1443 to APM); and Universidad Nacional del Sur (Grants PGI 24/B282 to SSA and PGI 24/B279 to JC).

"Corresponding authors: silviant@criba.edu.ar; jcorradi@criba.edu.ar; apmurray@uns.edu.ar

Reprint requests: Silvia Susana Antollini, Instituto de Investigaciones Bioquímicas de Bahía Blanca, Departamento de Biología, Bioquímica y Farmacia, Universidad Nacional del Sur y Consejo Nacional de Investigaciones Científicas y Técnicas, Camino La Carrindanga km 7 , 8000 Bahía Blanca, Argentina. Telephone: 0054291437 5574. silviant@criba.edu.ar

${ }^{1}$ Instituto de Investigaciones Bioquímicas de Bahía Blanca, Departamento de Biología, Bioquímica y Farmacia, Universidad Nacional del Sur y Consejo Nacional de Investigaciones Científicas y Técnicas, Camino La Carrindanga km 7, 8000 Bahía Blanca, Argentina

${ }^{2}$ Instituto de Química del Sur, Departamento de Química, Universidad Nacional del Sur y Consejo Nacional de Investigaciones Científicas y Técnicas, Av. Alem 1253, 8000 Bahía Blanca, Argentina

No author has an actual or perceived conflict of interest with the contents of this article. 
Molecular Pharmacology Fast Forward. Published on December 30, 2021 as DOI: 10.1124/molpharm.121.000415 This article has not been copyedited and formatted. The final version may differ from this version. 
Molecular Pharmacology Fast Forward. Published on December 30, 2021 as DOI: 10.1124/molpharm.121.000415

This article has not been copyedited and formatted. The final version may differ from this version.

Table 1. Inhibition of cholinesterase activity by compounds 7-11 and their corresponding precursors. Tacrine was tested as a control of AChE inhibition. ND= not detected.

\begin{tabular}{lll}
\hline Compound & $\begin{array}{l}\mathrm{IC}_{50} \\
(\mu \mathrm{M})\end{array}$ & $\log \mathrm{IC}_{50} \pm \mathrm{SD}$ \\
\hline Theophylline & 473.0 & $2.675 \pm 0.0787$ \\
Pyrrolidine & $\mathrm{ND}$ & \\
Caffeine & 87.0 & $1.939 \pm 0.0562$ \\
Compound 7 & 56.2 & $1.750 \pm 0.0310$ \\
Compound 8 & 21.8 & $1.337 \pm 0.0442$ \\
Compound 9 & 13.5 & $1.130 \pm 0.0259$ \\
Compound 10 & 6.1 & $0.7849 \pm 0.0447$ \\
Compound 11 & 0.22 & $-0.6655 \pm 0.0593$ \\
Tacrine & 0.029 & $-1.53 \pm 0.05$ \\
\hline
\end{tabular}


Table 2. Binding energy and interacting residues. The best binding energy (BBE) of the most stable conformation obtained after docking analyses is shown for each ligand. All the interacting residues observed in the different conformations are listed for each ligand. Residues reported as relevant for enzymatic activity are shown in bold (with residues from the CAS in grey and from the PAS in black). Data correspond to three independent docking experiments.

\begin{tabular}{lllllllll}
\hline Ligand & $\begin{array}{r}\text { BBE } \pm \text { SD } \\
\text { (Kcal/mol) }\end{array}$ & & & & Interacting residues & \\
& $-4.91 \pm 0.11$ & W86 & G122 & S203 & R296 F338 & H447 & \\
\hline ACh & & G121 & E202 & F295 & Y337 & Y341 & & \\
Donepezil & $-11.88 \pm 0.24$ & D74 & Y124 & S293 & R296 & Y341 & & \\
& & W86 & W286 & F295 & Y337 & H447 & & \\
Theophylline & $-5.31 \pm 0.02$ & Y72 & L289 & V294 & R296 & F338 & & \\
& & W286 & S293 & F295 & F297 & Y341 & & \\
Pyrrolidine & $-4.78 \pm 0.01$ & W86 & & & & & & \\
& & E202 & & & & & & \\
Compound 7 & $-8.56 \pm 0.07$ & Y72 & W86 & S293 & F295 & Y341 & & \\
& & D74 & W286 & V294 & F297 & & & \\
Compound 8 & $-8.95 \pm 0.13$ & Y72 & W86 & W286 & V294 F297 & & \\
& & D74 & Y124 & S293 & F295 & Y341 & & \\
Compound 9 & $-9.46 \pm 0.08$ & Y72 & W86 & W286 & V294 & F297 & Y341 & \\
& & D74 & Y124 & S293 & F295 & F338 & & \\
Compound 10 & $-9.59 \pm 0.07$ & Y72 & W86 & W286 & S293 F295 & F297 & F338 \\
& & D74 & Y124 & L289 & V294 R296 & Y337 & Y341 \\
Compound 11 & $-9.79 \pm 0.10$ & Y72 & W86 & E202 & S293 F295 & Y337 & Y341 \\
& & D74 & Y124 & W286 & V294 F297 & F338 & H447 \\
\hline
\end{tabular}


Molecular Pharmacology Fast Forward. Published on December 30, 2021 as DOI: 10.1124/molpharm.121.000415

This article has not been copyedited and formatted. The final version may differ from this version.

\section{FIGURE CAPTIONS}

Scheme 1. Synthesis of derivatives 7-11. a) anh. $\mathrm{K}_{2} \mathrm{CO}_{3}$, dry DMF, MW; b) dry DMF, MW.

Figure 1. AChE inhibitors and nAChR agonist (nicotine), base structures for the design of new caffeine analogs as AChE inhibitors and nAChR modulators.

Figure 2. Activation of the muscle $n A C h R$ by the synthetized caffeine analogs $7-11$. Singlechannel events elicited by $30 \mu \mathrm{M}$ ACh or $10 \mu \mathrm{M}$ of pyrrolidine, theophylline and each compound. Openings were recorded at $-70 \mathrm{mV}$ of membrane potential and they are shown as upward deflections.

Figure 3. Activation profile of muscle nAChR at various concentrations of compound 9. Openings were recorded at $-70 \mathrm{mV}$ of membrane potential and they are shown as upward deflections. On the right of each trace are the open- (top) and closed-duration histograms (bottom) obtained for each condition.

Figure 4. Neuronal $\alpha 7$ receptor activation by synthetized compounds. A) Single-channel events obtained from cells transfected with human $\alpha 7$ receptor and activated by $100 \mu \mathrm{M}$ ACh in the absence (top) or presence (bottom) of $1 \mu \mathrm{M}$ PNU. B). Similar events were elicited by $10 \mu \mathrm{M}$ of compound 9. Events were obtained from cell-attached configuration at $-70 \mathrm{mV}$ membrane potential in the absence (top) or presence (bottom) of $1 \mu \mathrm{M}$ PNU.

Figure 5. $\mathrm{K}_{\mathrm{D}}$ values of $\mathrm{CrV}$ in the absence and presence of carb (white and grey columns, respectively) obtained in a control condition or after incubation with two different concentrations of pyrrolidine and theophylline. The dotted lines show the $\mathrm{CrV} \mathrm{K}_{\mathrm{D}}$ values for the receptor in resting $(R)$ and desensitized (D) states. Changes in $K_{D}$ were calculated with respect to the resting state "R" of the nAChR in the control condition. Each column represents the mean $\pm \mathrm{SD}$ of the total number of samples at each condition, each data is also shown. The comparisons were done between each experimental condition and the control condition without carb ("R" state) using randomized one-way ANOVA. Means from conditions sharing a letter ( $a$ or $b$ ) are not statistically different, while different letters denote highly significant differences $(p<0.01)$.

Figure 6. $K_{D}$ values of $C r V$ in the absence and presence of carb (white and grey columns, respectively) obtained before (control condition) or after incubation with two different 
concentrations ( $1 \mu \mathrm{M}$, lined pattern columns and $200 \mu \mathrm{M}$, empty columns) of compounds 7-11. The dotted lines show the $\mathrm{CrV} K_{D}$ values for the receptor in resting (R) and desensitized (D) states. Changes in $K_{D}$ were calculated with respect to the resting state "R" of the nAChR in the control condition. Each column represents the mean \pm SD of the total number of samples at each condition, each data is also shown. The comparisons were done between each experimental condition and the control condition without carb ("R" state) using randomized oneway ANOVA. Means from conditions sharing a letter ( $a, b$ or $c$ ) are not statistically different, while different letters denote highly significant differences $(p<0.01)$.

Figure 7. Molecular docking of various compounds into the CAS/PAS site of the human AChE. A) Representation as ribbons of the human AChE (PDB code 4EY7) with the best conformation of compounds 7-11 bound. A detailed view of the region indicated with the black square (dashed lines) is shown for donepezil (B), theophylline (C), pyrrolidine (D), compound $7(E)$ and compound $11(F)$ with their corresponding interactions as dashed lines. Cation-m is shown in orange, $\pi$-alkyl in pink, $\pi-\pi$ in purple and $\mathrm{H}$-bond in green.

Figure 8. Molecular docking of various compounds into the $n A C h R$ orthosteric binding site. A) Structure representation of the extracellular domain of the mouse $n A C h R$. The $\alpha 1 / \delta$ partially capped model interface is shown as ribbons, with $\alpha 1$ subunit in blue (principal face) and $\delta$ subunit in green (complementary face). The best conformation of compounds 7-11 is depicted in the orthosteric binding site. A detailed view of the region indicated with the black square (dashed lines) is shown for $A C h(B)$, pyrrolidine $(C)$, theophylline (D), compound 7 (E) and compound 11 (F) with their corresponding interactions as dashed lines. Cation-m is shown in orange, $\pi$-alkyl in pink, $\pi-\pi$ in purple and $\mathrm{H}$-bond in green. For each ligand similar results were obtained with the corresponding $\alpha 1 / \varepsilon$ models (not shown). For $A C h(B)$ and pyrrolidine $(C)$ the subunit interface corresponds to the $\alpha 1 / \delta$ capped model. 
Molecular Pharmacology Fast Forward. Published on December 30, 2021 as DOI: 10.1124/molpharm.121.000415 This article has not been copyedited and formatted. The final version may differ from this version. 


\section{Scheme 1}

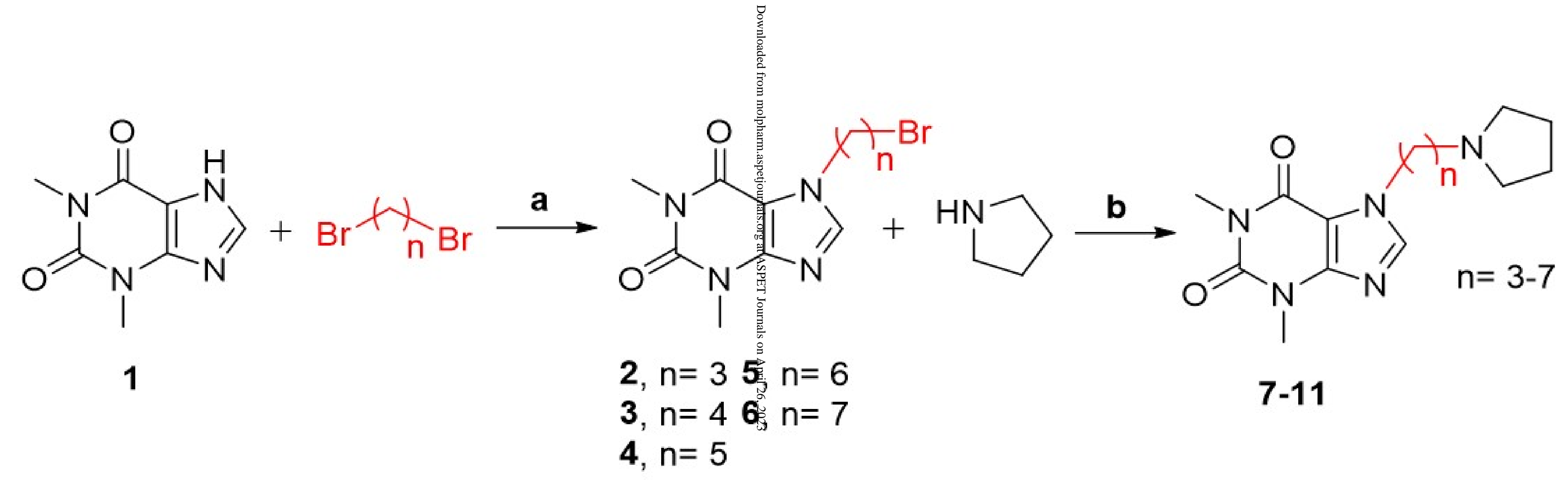


Figure 1.
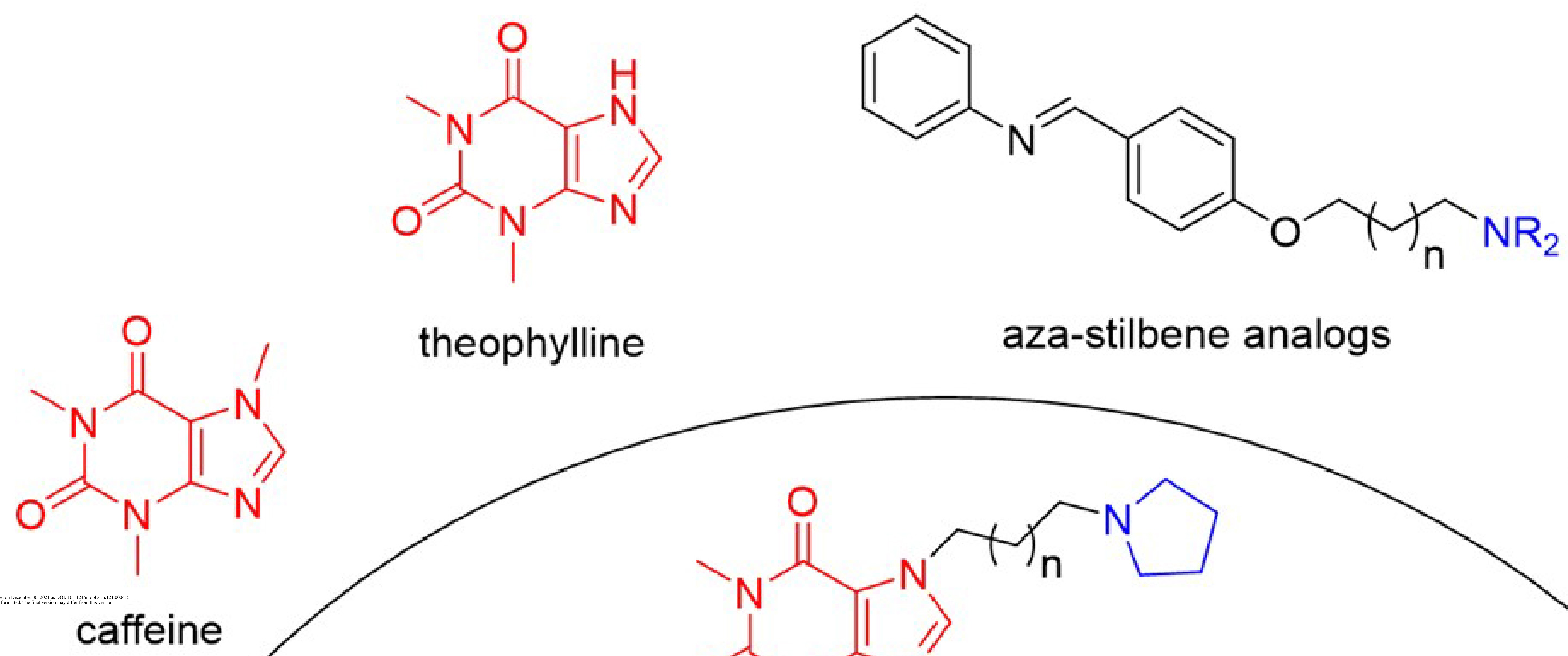

theophylline

aza-stilbene analogs
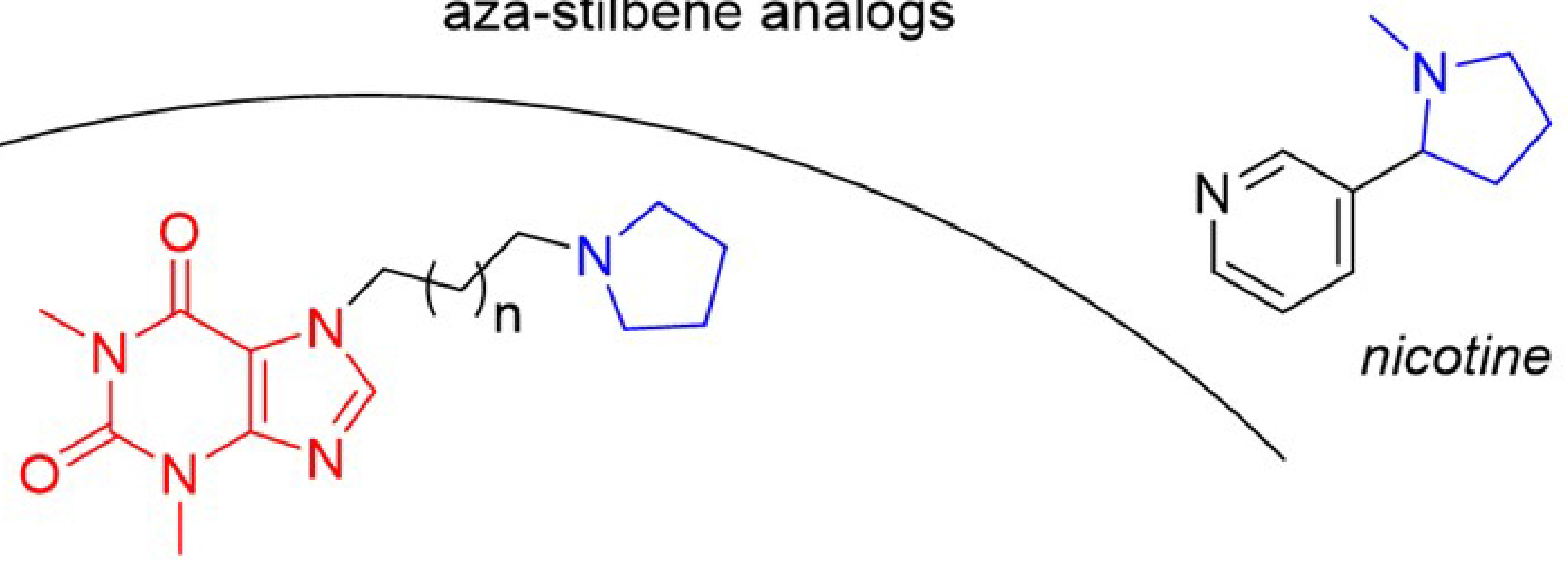

New caffeine analogs 
Figure 2.
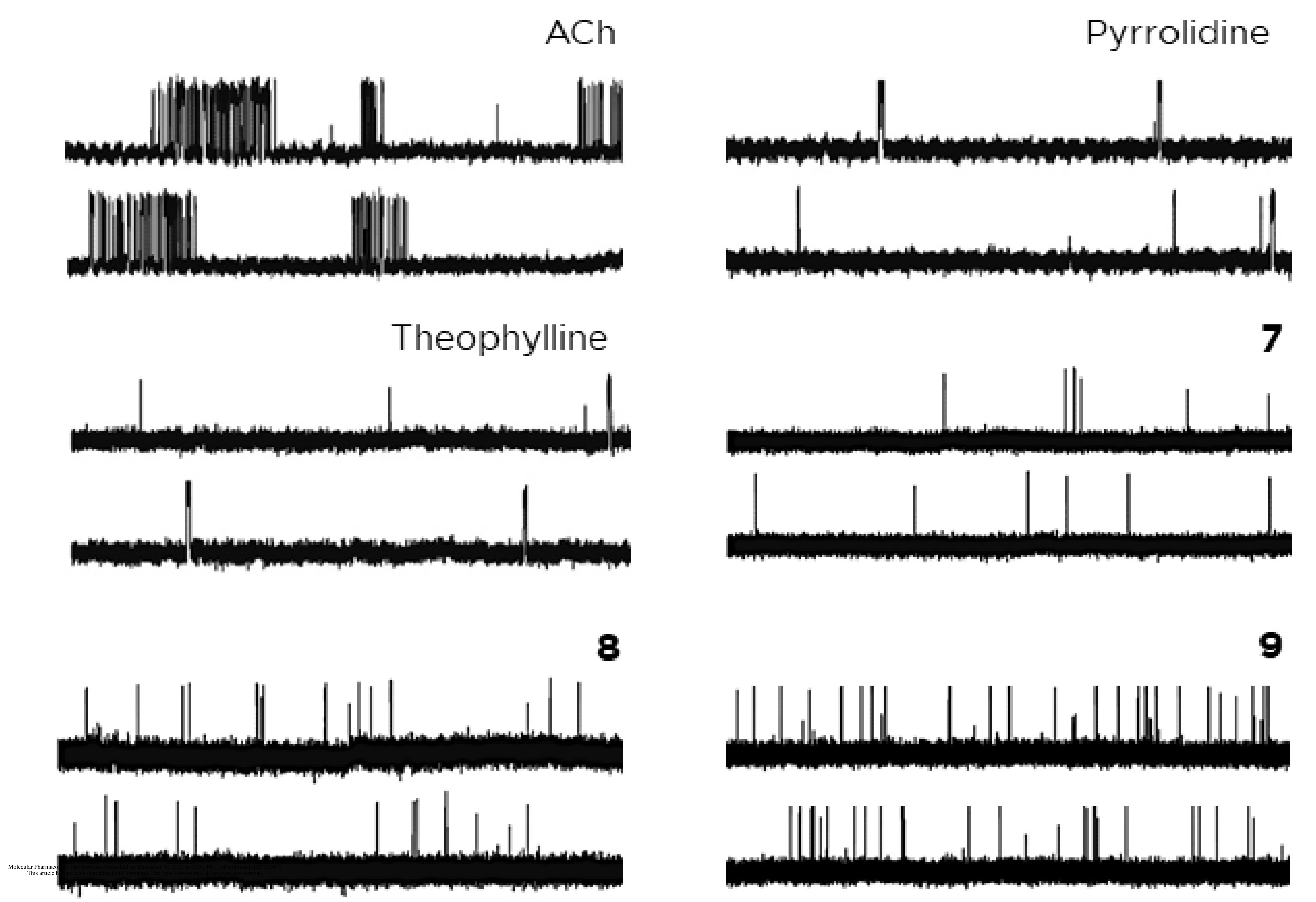

10
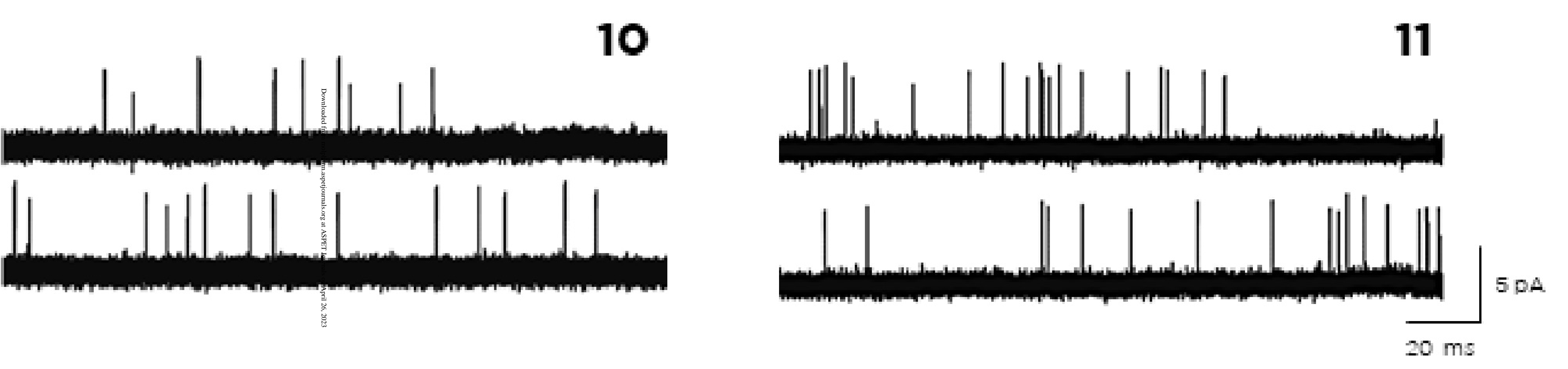
Figure 4.

A

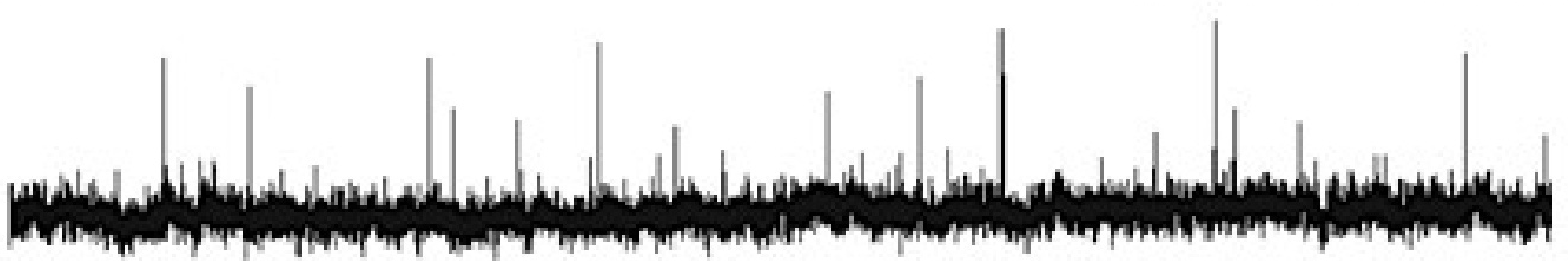

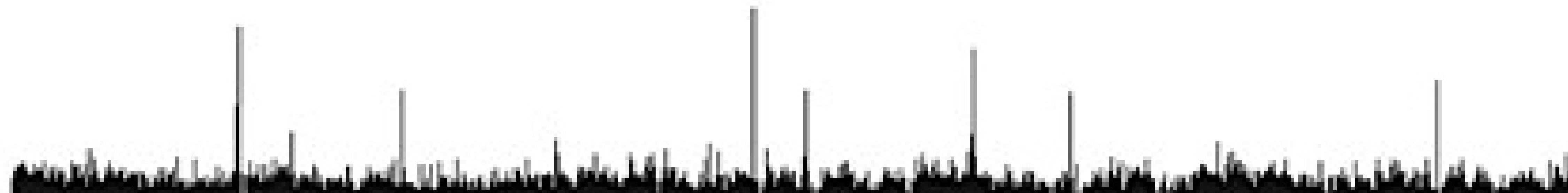

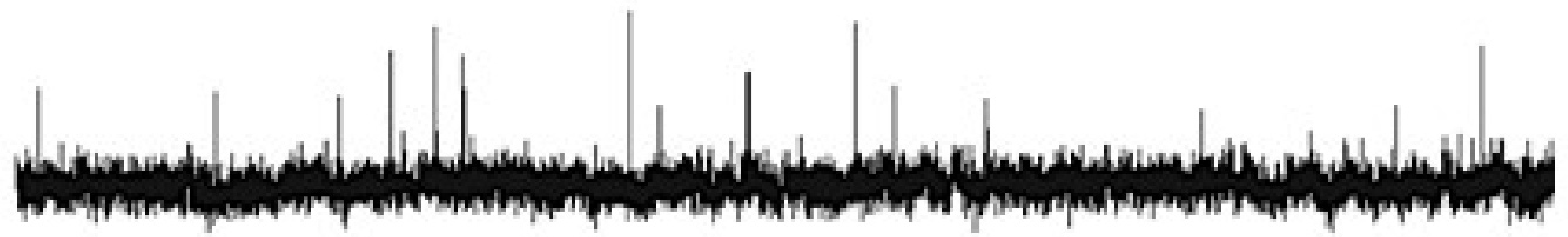
$100 \mu \mathrm{M} \mathrm{ACh}+1 \mu \mathrm{M}$ PNU

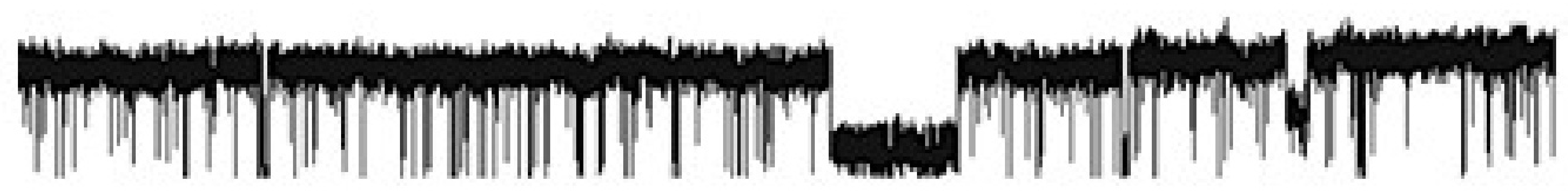

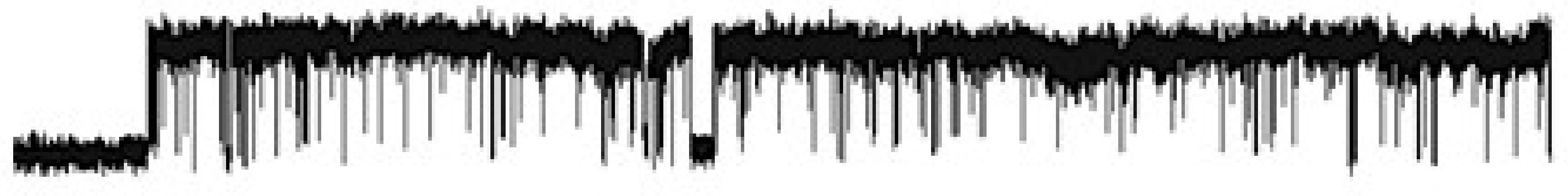
mymm mTintim $\int_{\text {ming }}$
B
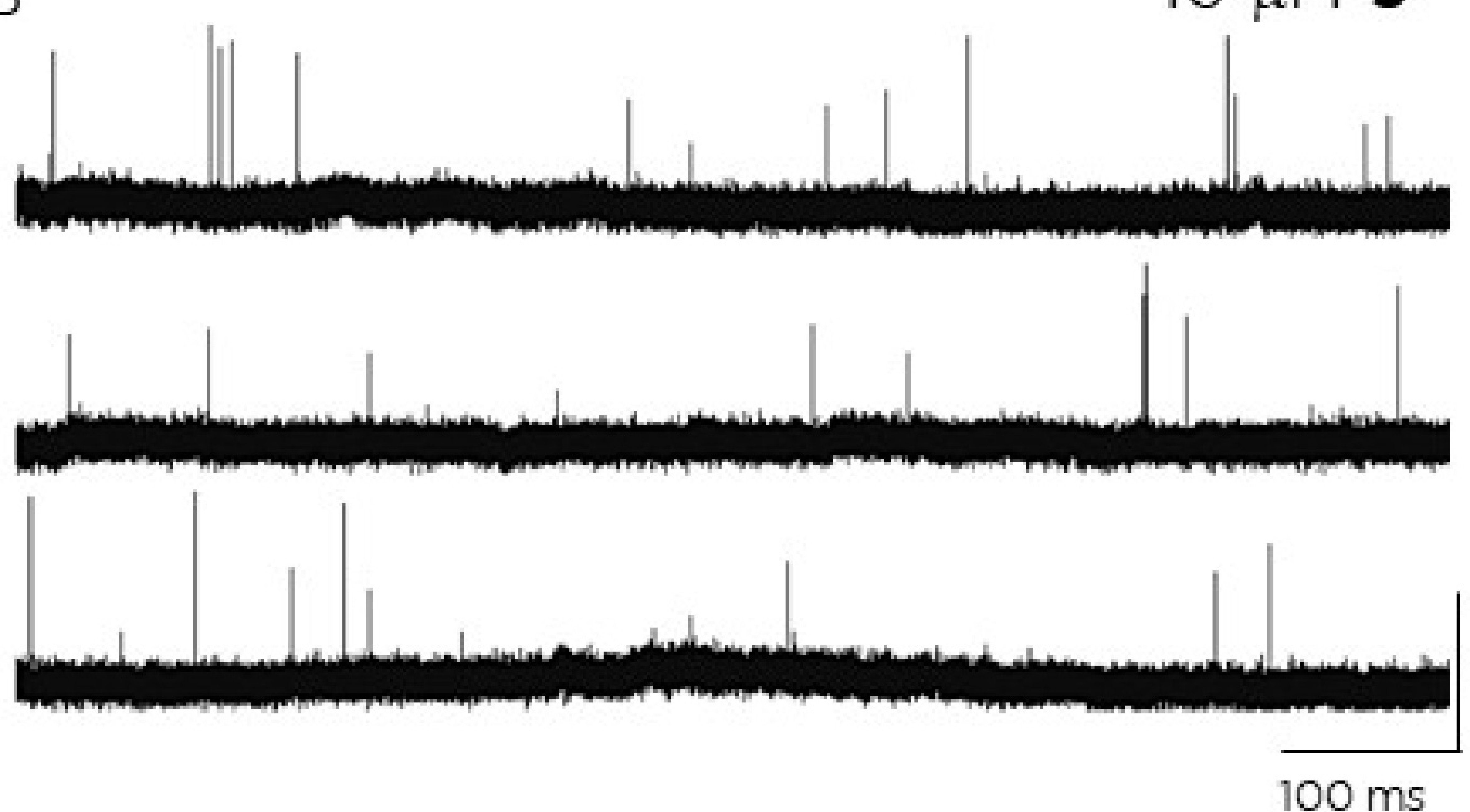

$10 \mu \mathrm{M} 9+1 \mu \mathrm{M}$ PNU
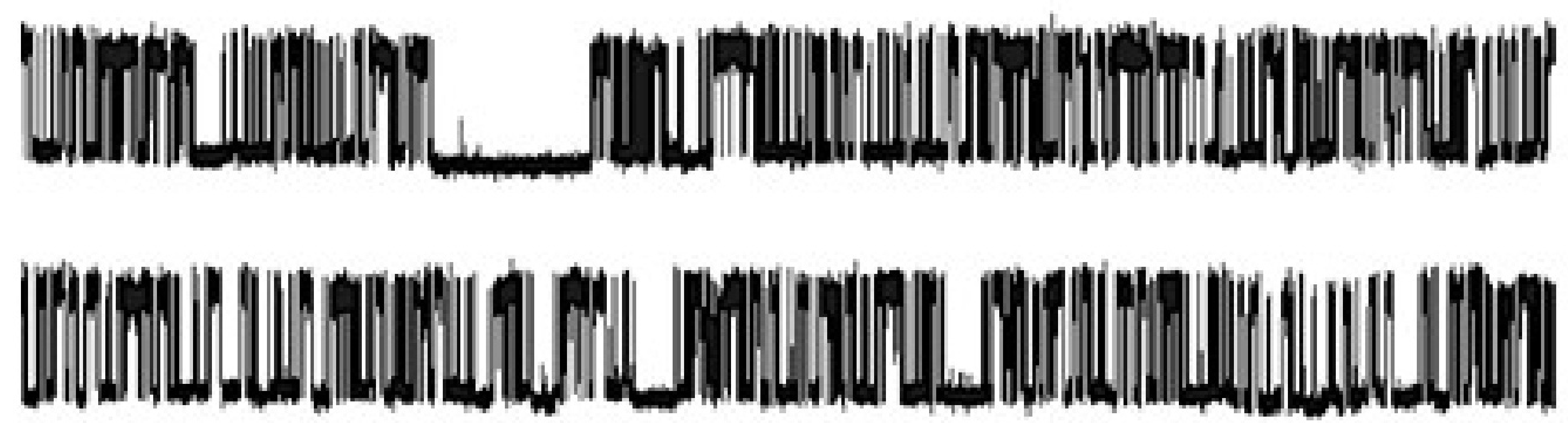

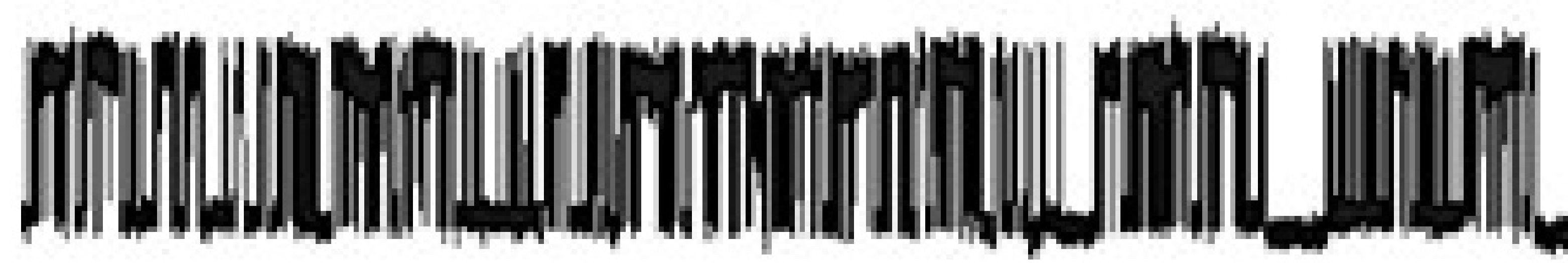
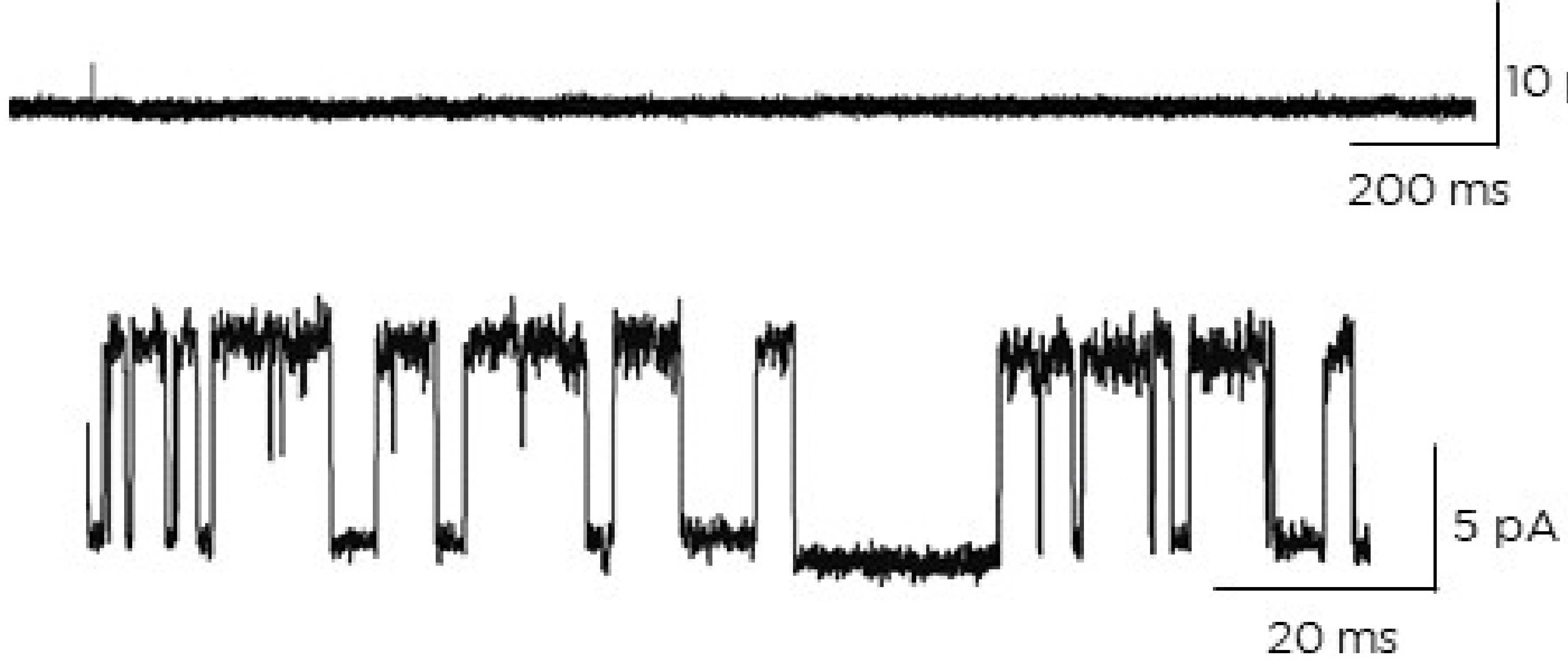
Figure 5.

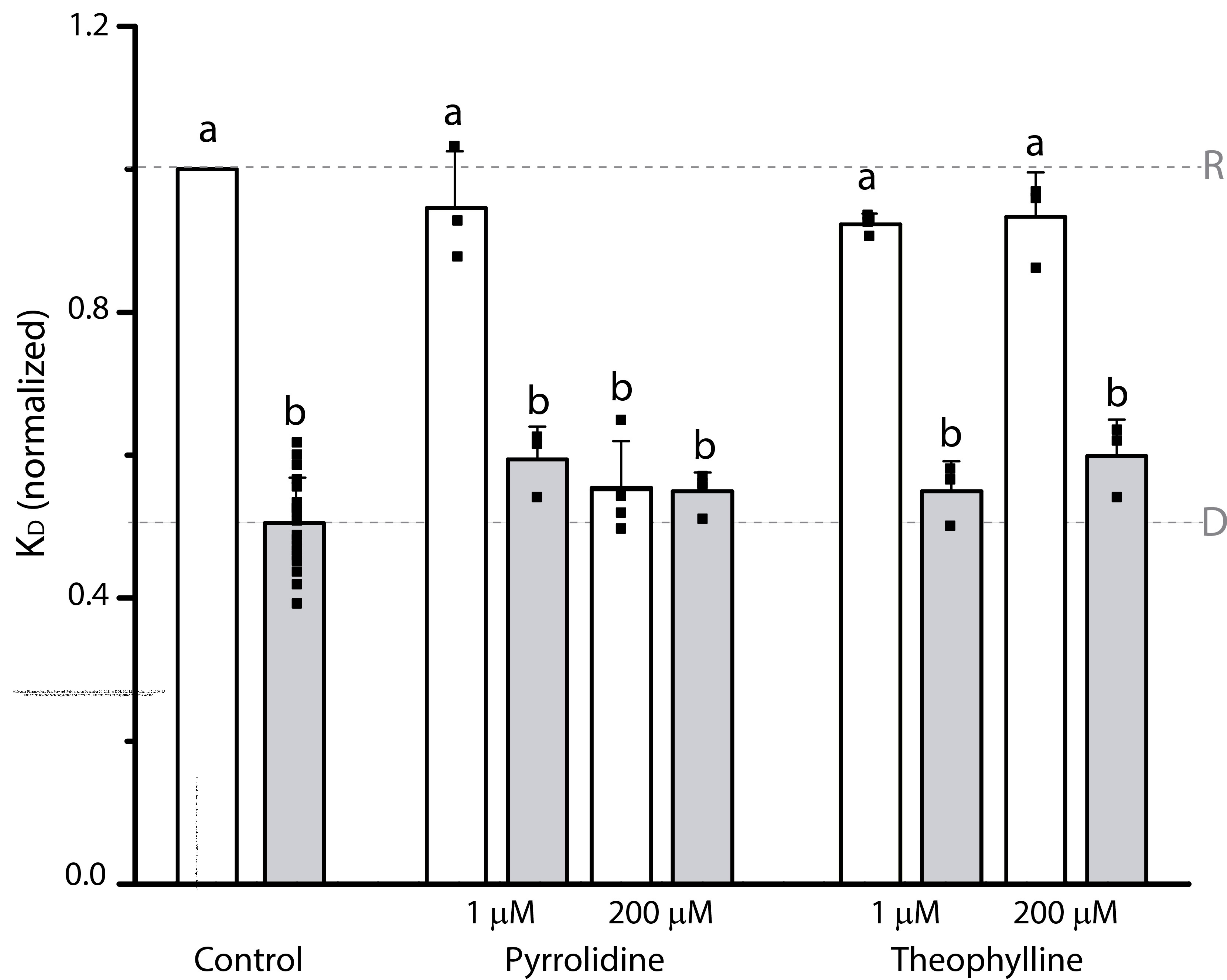


Figure 6.

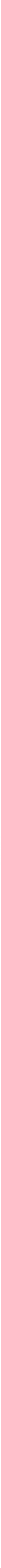



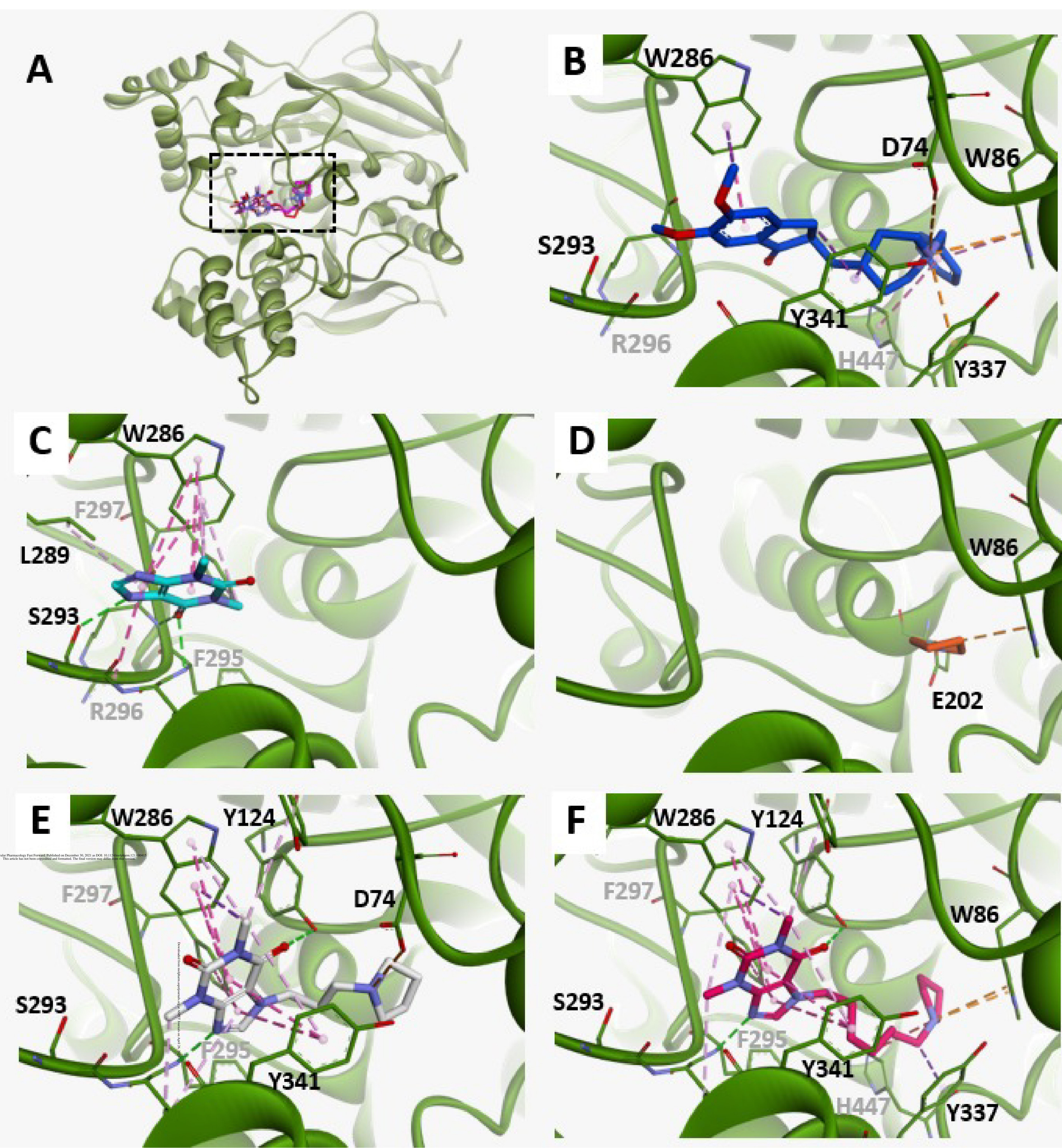

Figure 7.

A

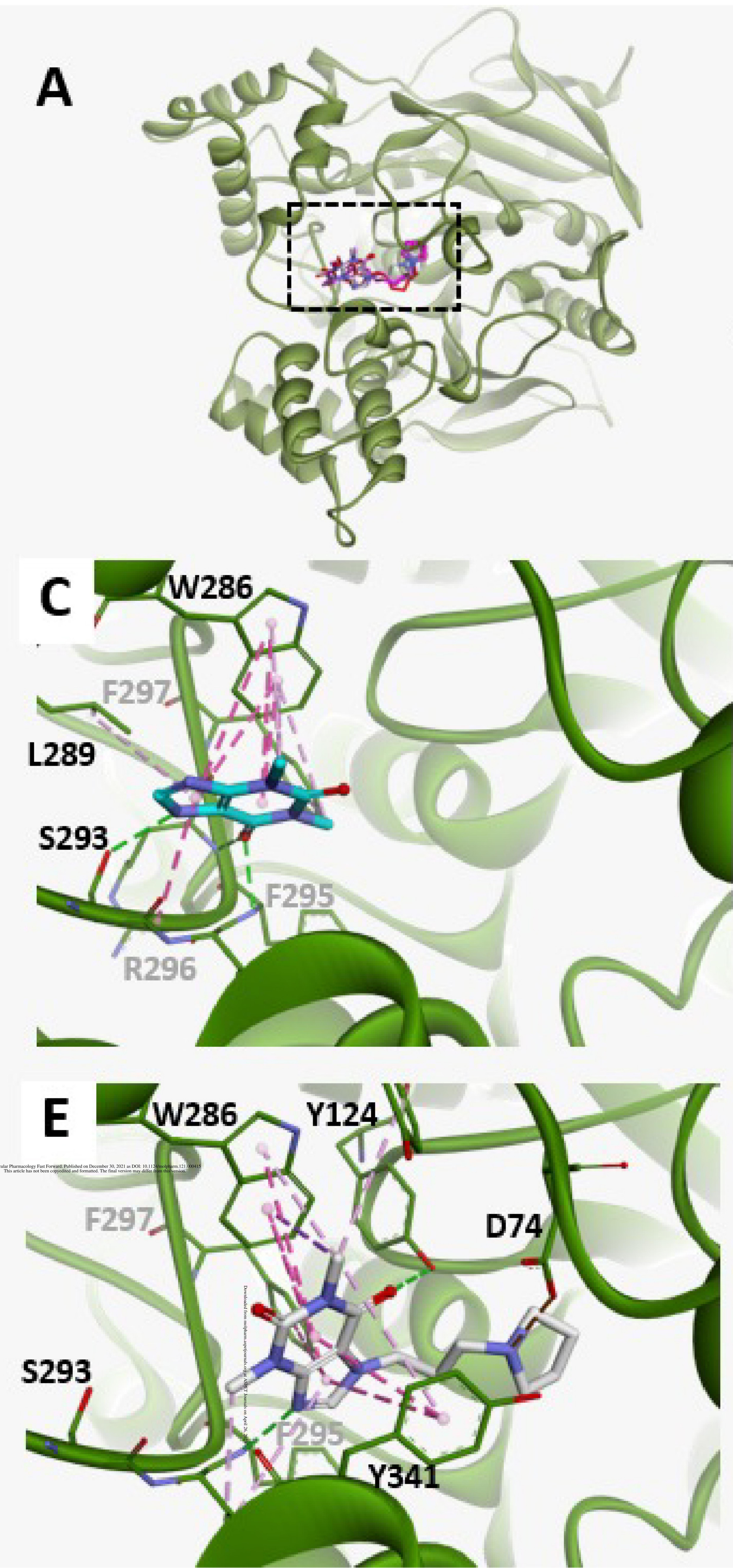

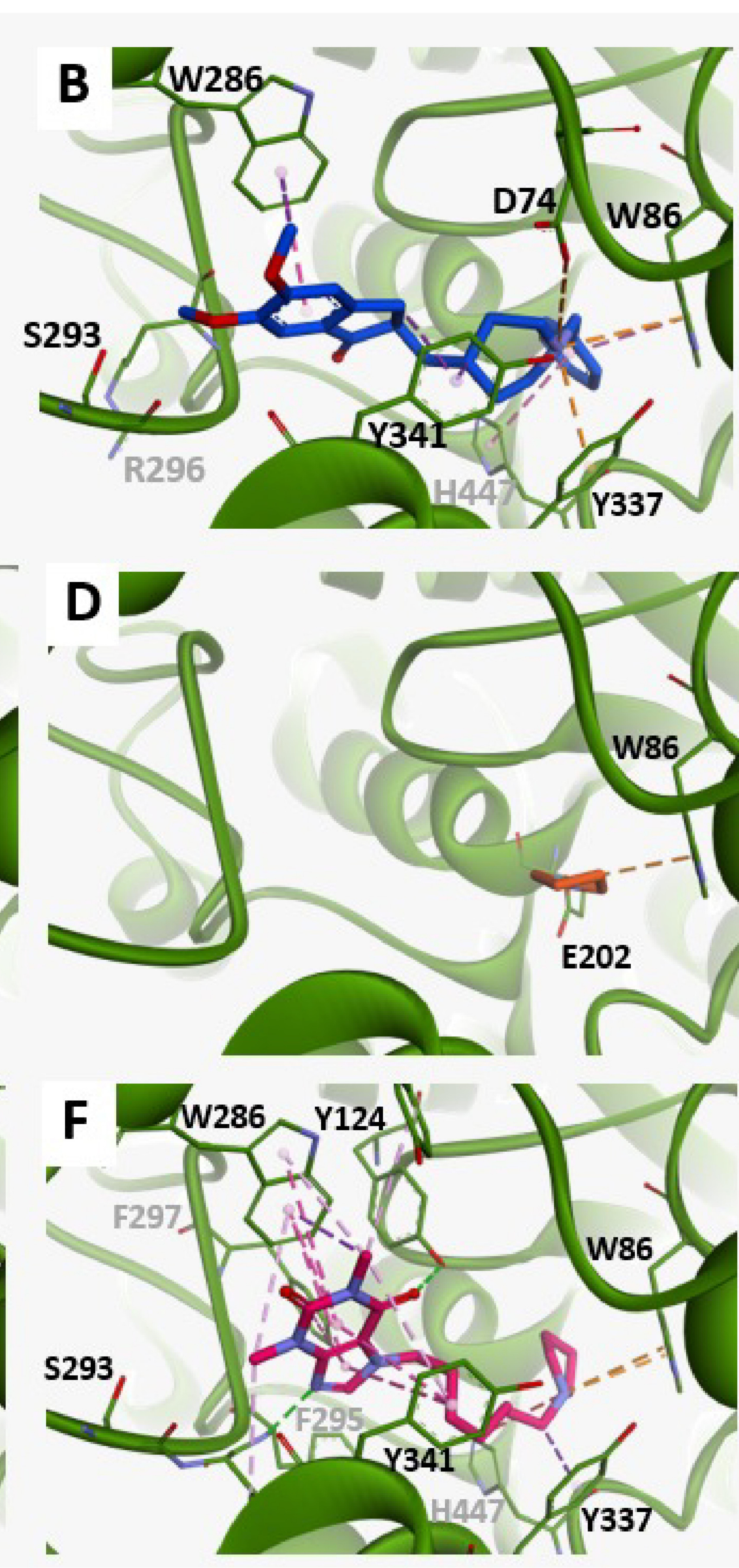



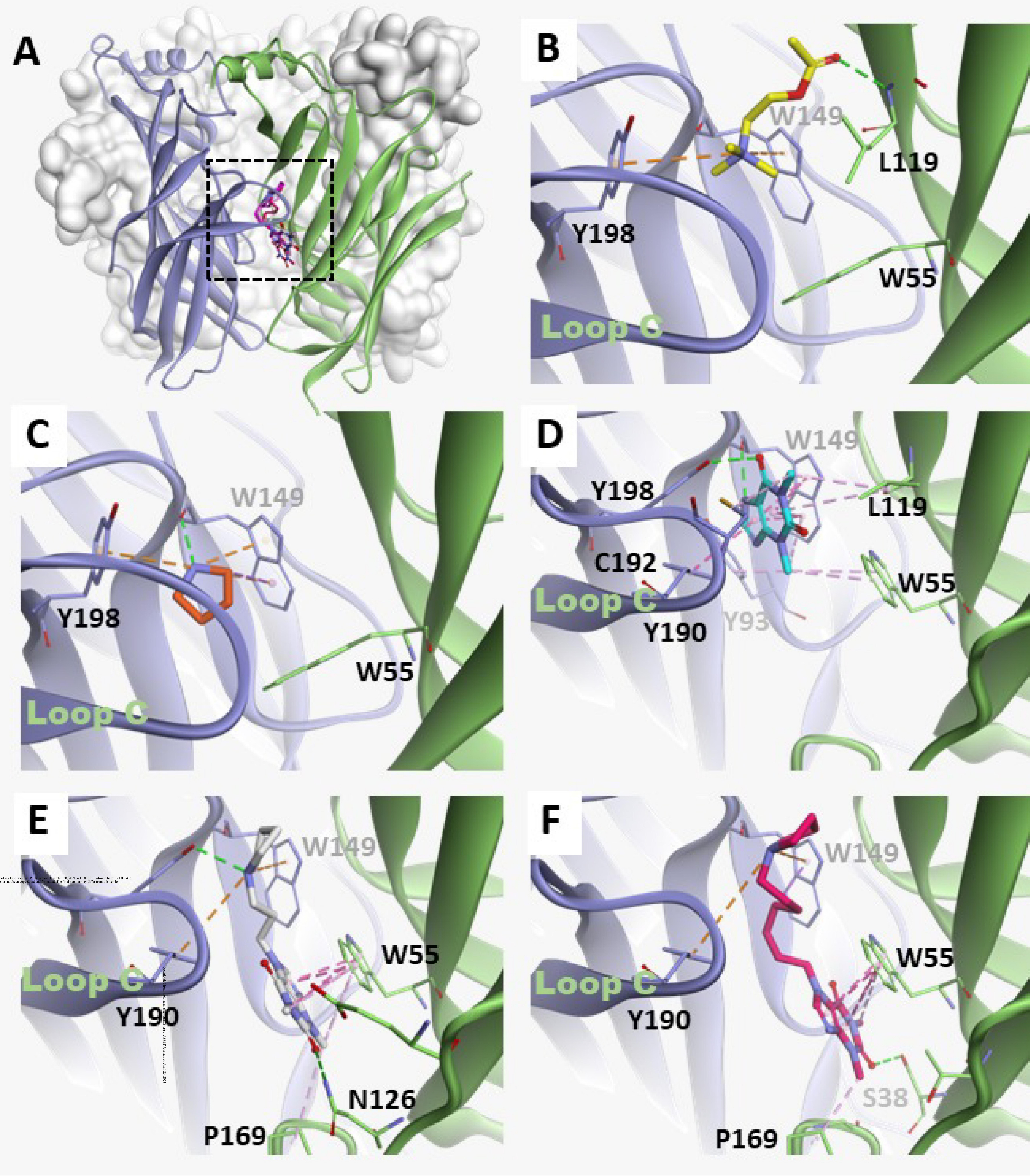

Figure 8.

A 